\title{
31. PALYNOLOGY AND DINOCYST BIOSTRATIGRAPHY OF THE LATE MIOCENE TO PLEISTOCENE, NORWEGIAN SEA: ODP LEG 104, SITES 642 TO 6441,2
}

\author{
Peta J. Mudie ${ }^{3}$
}

\begin{abstract}
Cores from ODP Leg 104 Holes 642A, 642B, 642C, 644A, and 644B were sampled at intervals of $40 \mathrm{~cm}$ to $100 \mathrm{~cm}$ for a detailed study of palynomorphs and palynodebris types in upper Cenozoic sediments of the Vøring Plateau. Corecatcher samples were also studied from Hole 643A on the seaward flank of the plateau. Most of the 600 samples studied contained dinoflagellate cysts, pollen, spores, and various types of palynodebris. Total numbers of indigenous dinocysts, and pollen-spore concentrations show cyclical variations which appear to correspond to climate fluctuations in Pliocene and younger sediments, and to either climatic changes or phytoplankton productivity cycles in the older sediments. Stratigraphic ranges for 68 cyst morphotypes were used to erect a provisional dinocyst zonation that can be correlated with other Northern Hemisphere high-latitude zonations. Four dinocyst zones are defined, with boundaries corresponding to biochronological or magnetostratigraphic ages of $\mathrm{ca} .15 \mathrm{Ma}, 9 \mathrm{Ma}, 4.2 \mathrm{Ma}$, and 1.4 Ma. Environmental changes are interpreted in terms of (a) a progressive decline in species diversity due to the disappearance of subtropical species; (b) appearance of subarctic North Pacific taxa, presumably from the Arctic Ocean; and (c) an increase in heterotrophic protoperidinioid cyst species during the Pleistocene.
\end{abstract}

\section{INTRODUCTION}

On Leg 104 of the Ocean Drilling Program, Cenozoic sediments were drilled at three sites on a transect across the Vøring Plateau in the eastern Norwegian-Greenland Sea (Fig. 1). The Vøring Plateau is a marginal plateau that extends westward from the Norwegian Shelf at a water depth of ca. $1400 \mathrm{~m}$ (Fig. 2), then descends to the Lofoten Basin and the Norway Basin on the north and south sides, respectively. At present, the Norwegian Current transports warm, saline North Atlantic Drift water northward over the Iceland-Faroe Ridge, and the East Greenland Current transports cold water from the Arctic Ocean southward to the North Atlantic through the Denmark Strait (Fig. 1). The Vøring Plateau is thus well located for detailed study of the paleoclimatic and oceanographic evolution of the high-latitude eastern North Atlantic region, including its responses to Cenozoic global climatic changes and the tectonic history of the sills and channels which link the Norwegian-Greenland Sea with the Atlantic and Arctic Oceans. This paper reports the results of high-resolution studies of palynomorphs and palynodebris in the upper Cenozoic sediments, and it presents a detailed dinocyst biostratigraphy which clarifies and refines the initial shipboard results reported by Mudie in Eldholm, Thiede, Taylor, et al. (1987).

On Leg 104, six holes were continuously cored using the advanced hydraulic piston corer to obtain detailed records of the sedimentological and paleoceanographic histories of the sites shown in Figure 2.

The primary purposes of this report are as follows:

1. To compare the palynological assemblages from the nearshore to offshore parts of the Vøring Plateau transect;

2. To establish a regional dinocyst biostratigraphy for the upper Miocene through Pleistocene sediments and its correla-

\footnotetext{
${ }^{1}$ Eldholm, O., Thiede, J., Taylor, E., et al., 1989. Proc. ODP, Sci. Results, 104: College Station, TX (Ocean Drilling Program).

2 Geological Survey of Canada, Contribution No. 88162.

${ }^{3}$ Geological Survey of Canada, Atlantic Geoscience Centre, Box 1006 Dartmouth, Nova Scotia B2Y 4A2, Canada.
}

tion with other North Atlantic and high-latitude palynostratigraphies;

3. To interpret the palynostratigraphic data in terms of paleoclimatic changes which occurred during the late Cenozoic.

During Leg 104, shipboard palynological studies (Eldholm, Thiede, Taylor, et al., 1987) were made from about 250 samples in an attempt to erect a Cenozoic dinocyst biozonation by correlation with data from DSDP Leg 38 in the Norwegian Sea (Manum, 1976) and with zonations described for deep-sea areas south of the Iceland-Faroe Ridge, e.g., DSDP Leg 94, Site 611 (Mudie, 1986), DSDP Leg 81 (Edwards, 1984), and DSDP Leg 48 (Costa and Downie, 1979; Harland, 1979). Results of the initial Leg 104 shipboard studies were very tentative, however, because of the following limitations:

1. Onboard laboratory processing facilities precluded routine use of HF digestion so that palynomorph concentrations (number per gram) were often low, and detailed cyst morphology was difficult to discern;

2. Large-scale variations in palynomorph concentration and composition characterize most high-latitude upper Cenozoic deep-sea sediments (Mudie, 1986); shipboard examination of core-catcher samples alone therefore provided a very limited perspective of the total palynoflora;

3. Many Norwegian Sea dinocyst species have not yet been described (Manum, 1976; Manum and Boulter, this volume), and there are still many uncertainties regarding equivalence of North Atlantic Neogene taxa reported by different workers (Head et al., in press a, b; de Vernal and Mudie in press a, b).

For the postcruise studies reported in this paper, 500 core section samples and 50 new catcher samples were processed using the same laboratory method as Manum and Boulter (this volume), who have made detailed studies of the early Cenozoic palynology at Sites 643 and 642 . Use of the same processing methods allows close comparison of morphotypes from all ODP Leg 104 palynological samples. Many dinocyst species identifications have been cross-checked with Manum and other workers studying Neogene dinocysts, but there is still need for sample exchange, comparative study, and stabilization of nomenclature. The late Cenozoic dinocyst zonation presented in this paper 


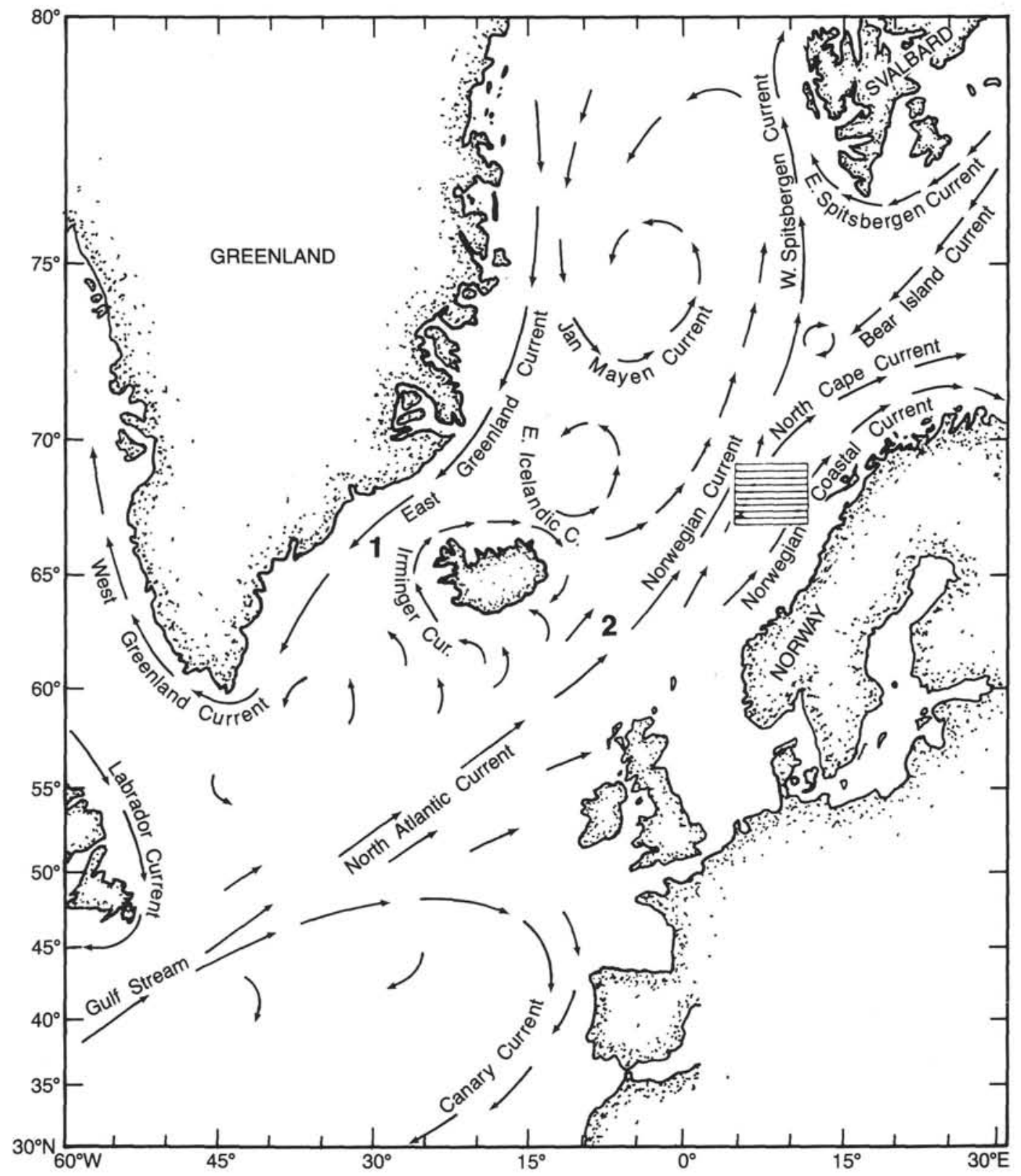

Figure 1. Location of the Vøring Plateau area (shaded square) in the Norwegian-Greenland Sea and the modern surface current circulation. $1=$ Denmark Strait; 2 = Iceland-Faeroe Ridge.

may therefore be refined on completion of these taxonomic studies in 1988.

\section{METHODS}

Sediment samples $\left(8-\mathrm{cm}^{3}\right.$ volume) representing 2-cm-long core segments were taken at intervals of 40 to $100 \mathrm{~cm}$ for cores from Sites 642 and 644 , but only catcher samples were available for Site 643. Samples were disaggregated in $1 \%$ Calgon solution and sieved through screens with mesh openings of 150 and $10 \mu \mathrm{m}$. The silt-fine sand fraction was sequentially processed with hot $\mathrm{HCl}$ and $\mathrm{HF}$ to remove carbonates and silicates, respectively, and one Lycopodium tablet was added to the residue to provide a basis for estimating palynomorph concentration (for details, see Mudie, 1986). Residues were stained with Safranin-O and strew mounts were made for palynodebris and biostratigraphic studies. Many preparations, however, contained too much amorphous organic debris to allow detailed study of dinocyst morphology. For these samples, aliquots of the residues were processed further using brief oxida- tion with $\mathrm{NaClO}$ and $\mathrm{HCl}$, following Evitt (1984). This oxidation method is the best one for removing fine detritus that obscures palynomophs in many samples of high-latitude marine sediments (Manum, 1976; Mudie, 1986), but it severely damages thin-walled protoperidinioid dinocysts and it cannot be used for routine palynological processing.

Slides were first examined with a Zeiss Universal microscope and Orthoplan $(\times 16)$ or Normarski interference contrast objectives $(\times 40$ and $\times 100$ ). Each slide was scanned at $\times 160$ magnification, Polaroid photographs were taken to record palynodebris amount and type, and all known taxa were recorded. Taxonomic verifications were then made at magnifications of $\times 400$ and $\times 1000$, and counts were made for a total of up to 200 dinocysts. Reworked Paleogene and older palynomorphs were recognized on the basis of their morphology. Reworked Neogene palynomorphs were mostly recognized by their yellow color (i.e., absence of staining with Safranin-O), or by their flat shape and presence of mineral imprints. Some questionable specimens were also examined by fluorescence microscopy and were counted as reworked if their fluorescence emission was lower than the average for in-situ palynomorphs of similar morphology. 


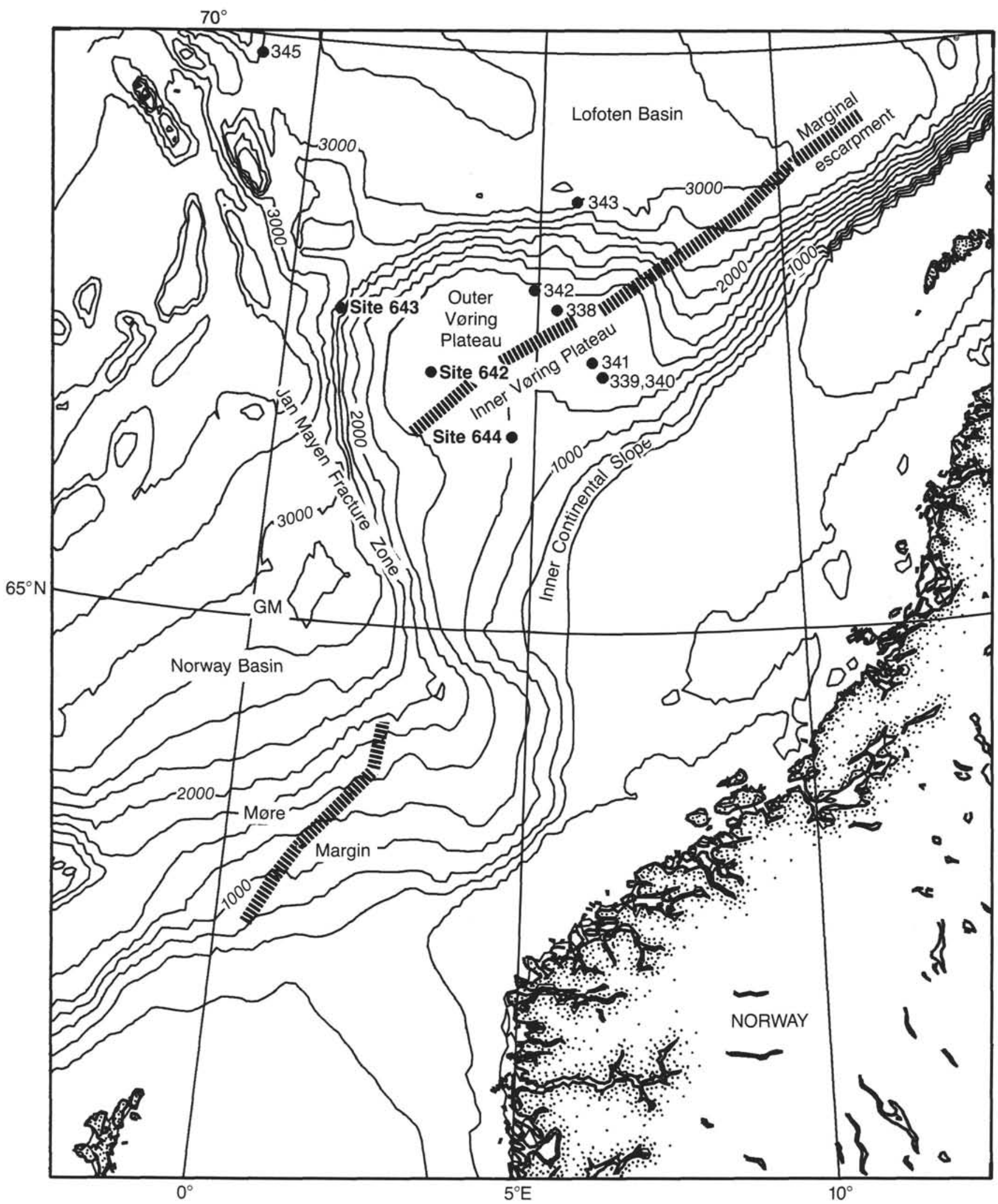

Figure 2. Bathymetric map of the Vøring Plateau area, showing locations of ODP Sites 642,643 , and 644 . Contour interval $250 \mathrm{~m}$. 


\section{PALYNODEBRIS TYPES AND QUANTITY}

About 600 samples from the Vøring Plateau sites were processed for palynological study of the upper Miocene to Pleistocene sediments. All except 20 of these contained dinocysts, pollen, spores, and various types of other acid-resistant plant material. The latter class of organic residues is referred to here as palynodebris. The term palynodebris therefore mainly refers to visual sedimentary organic matter as defined by Boulter and Riddick (1986) but it does not include the microplankton component (dinocysts, acritarchs), pollen, terrestrial plant and algal spores, foraminiferal linings, which are here referred to as palynomorphs. The main palynodebris types in the upper Cenozoic sediments include:

1. Amorphous matter-pale yellow or brown, partially translucent organic matter, often associated with black specks of fine pyrite or other material.

2. Wood fragments-well preserved wood cells with discernible wall structures, e.g., bordered pits, annular or spiral thickenings.

3. Leaf cuticle-leaf epidermis with well-defined cell structures.

4. Degraded debris-blocky, reddish particles without clearly discernible tissue structure.

5. Black debris-opaque, angular fragments with no discernible tissue structure.

The range of palynomorphs and palynodebris types found in the Vøring Plateau drill holes is shown in Plate 1. Graphs of concentrations (no. per $\mathrm{cm}^{3}$ sediment) of indigenous dinocysts and indigenous pollen and spores are shown in Figures 3 and 4; relative abundances of microphytoplankton are shown beside and on the dinocyst range charts (Figs. 5-10). Foraminiferal linings are present in almost all samples, with no clearly discernible stratigraphic distribution pattern; therefore they are not discussed further in this study.

Following the procedure of Manum (1976) for DSDP Leg 38, the palynomorph and palynodebris data can be synthesized to define general characteristics of the visual sedimentary matter in the Leg 104 drill holes, and to discern palynoevents, which are major changes in the ratio of marine dinocysts to terrestrial pollen and spores (Manum, 1976). The high-resolution sampling of Leg 104 cores reveals cyclical fluctuations in indigenous dinocyst and pollen and spore concentrations throughout the stratigraphic column at all three drill sites (Figs. 3 and 4). This cyclicity is superimposed on the palynoevent curves described by Mudie in the Leg 104 shipboard report. The new high-resolution data cast doubt on the validity of palynoevent curves as an index of regional paleoenvironmental changes when low-frequency sampling is used and when redeposited palynomorphs are grouped together with indigenous palynomorphs to calculate cyst ratios (Manum, 1976). The cyclical variations in indigenous palynomorphs, however, correspond to changes in palynodebris type and allow a tentative delimitation of palynofacies sequences (see Plate 1). Final interpretation of these palynofacies requires more closely spaced sampling of, and correlation with, stable isotopic data (Jansen et al., this volume), but an initial interpretation is presented here.

1. Upper Pliocene-Pleistocene sediments show intervals with common to abundant dinocysts $\left(>1000 / \mathrm{cm}^{3}\right)$ and $10 \%$ to $80 \%$ amorphous palynodebris (Plate 1, Figs. 1-7) alternating with intervals containing fewer dinocysts $\left(<100-500 / \mathrm{cm}^{3}\right),<10 \%$ or no amorphous debris, and abundant black debris, wood, and/or degraded debris. All of these samples also contain re- worked Cretaceous-Paleogene palynomorphs, with ratios of reworked/indigenous specimens being $>1$. The intervals with relatively high numbers of dinocysts correspond to all or part of interglacial stages and can be referred to as interglacial palynofacies. These frequently include coenobia of the freshwater algae Pediastrum and/or Botryococcus which are found in the vicinity of large rivers in modern arctic environments (Hill et al., 1985). The intervals with few dinocysts and abundant large particles of black debris or wood correspond to glacial stages or to intervals of ice rafted debris (IRD) deposition during interglacial stages.

2. There is a notable increase in amplitude of the interglacial palynomorph influxes between isotopic stages 9 and 11 , from ca. $347-440 \mathrm{Ka}$ (Fig. 3,35 to 43 mbsf in Hole $644 \mathrm{~B}$; 18 to 21 mbsf in Hole 642B); this increase is also associated with a change in the amount and nature of amorphous debris which increase in volume, become darker in color, and include abundant black specks. Freshwater algae also become less common. In the lower Pleistocene interval at Site 644, diatom fragments and/or black spores (pyritized diatoms; see Mudie, 1986) become common to abundant, but this change is not seen above the upper Pliocene interval at the more seaward location, Site 642 .

3. Large fluctuations in the amplitude of palynomorph frequencies appear throughout the lower Pliocene and Miocene intervals at Sites 642 and 643 , with the Miocene interval being distinguished by smaller declines in dinocyst concentrations. These troughs are also associated with reduced amounts of amorphous debris $(<50 \%)$ and, at Site 642 (Figs. 4 and 7 ), the troughs are correlated with increased abundances of diatoms, possibly indicating that dinoflagellate productivity was lower during intervals of frequent diatom blooms. Throughout the upper Miocene-lower Pliocene interval, particles of wood and black and unstructured debris particles are relatively small, and reworked Cretaceous-Paleogene palynomorphs are rare (ratio of reworked: indigenous specimens range from 0.01 to $<1.0$ ).

4. Middle to lower Miocene sediments at Site 643 (below ca. 119 mbsf, Fig. 3) appear to contain consistently high concentrations of indigenous dinocysts. This signal may indicate more uniformly favorable environmental conditions, but the sampling frequency (ca. one sample per m.y.) is too low to dismiss all possibility of large-amplitude cyclicity. The most notable feature of all samples from this interval is the large quantity of dinocysts and sparseness of palynodebris, pollen, spores, and diatoms.

5. There is an apparently slight decrease in palynomorph concentrations for equivalent time intervals from the inner to outer sites (Fig. 3). Sedimentation rates at the inner Site 644, however, are two to five times higher than at the middle Site 642 ; thus, the number of palynomorphs deposited per unit time is actually two to five times higher at Site 644 than appears on the graph. In contrast, the sedimentation rate at Site 642 is about $1 \mathrm{~cm} / \mathrm{ka}$ or less below the Jaramillo event (ca. 47 and $110 \mathrm{mbsf}$ in Holes 642B and 644B, respectively). The number of palynomorphs deposited per unit time at Site 642 is therefore the same or less than than the numbers shown on the graphs. This trend of decreased palynomorph abundance across the Vøring Plateau conflicts with the Leg 104 organic carbon data (Eldholm, Thiede, Taylor, et al., 1987) which show amounts of $<1 \%$ for upper Cenozoic sediments at Sites 644 and 643 and amounts of 0.4 to $1.8 \%$ for Site 642 . These conflicting data show that, in this area of complex currents, palynomorph content may be a poor index of total organic accumulation because strong bottom currents at the inner site (Site 644) and outer site (Site 643) reduce the deposition rates of fine-grained particulate organic matter. The nearshore-offshore trend from higher to lower palynomorph and palynodebris concentrations, however, is consistent with previous 


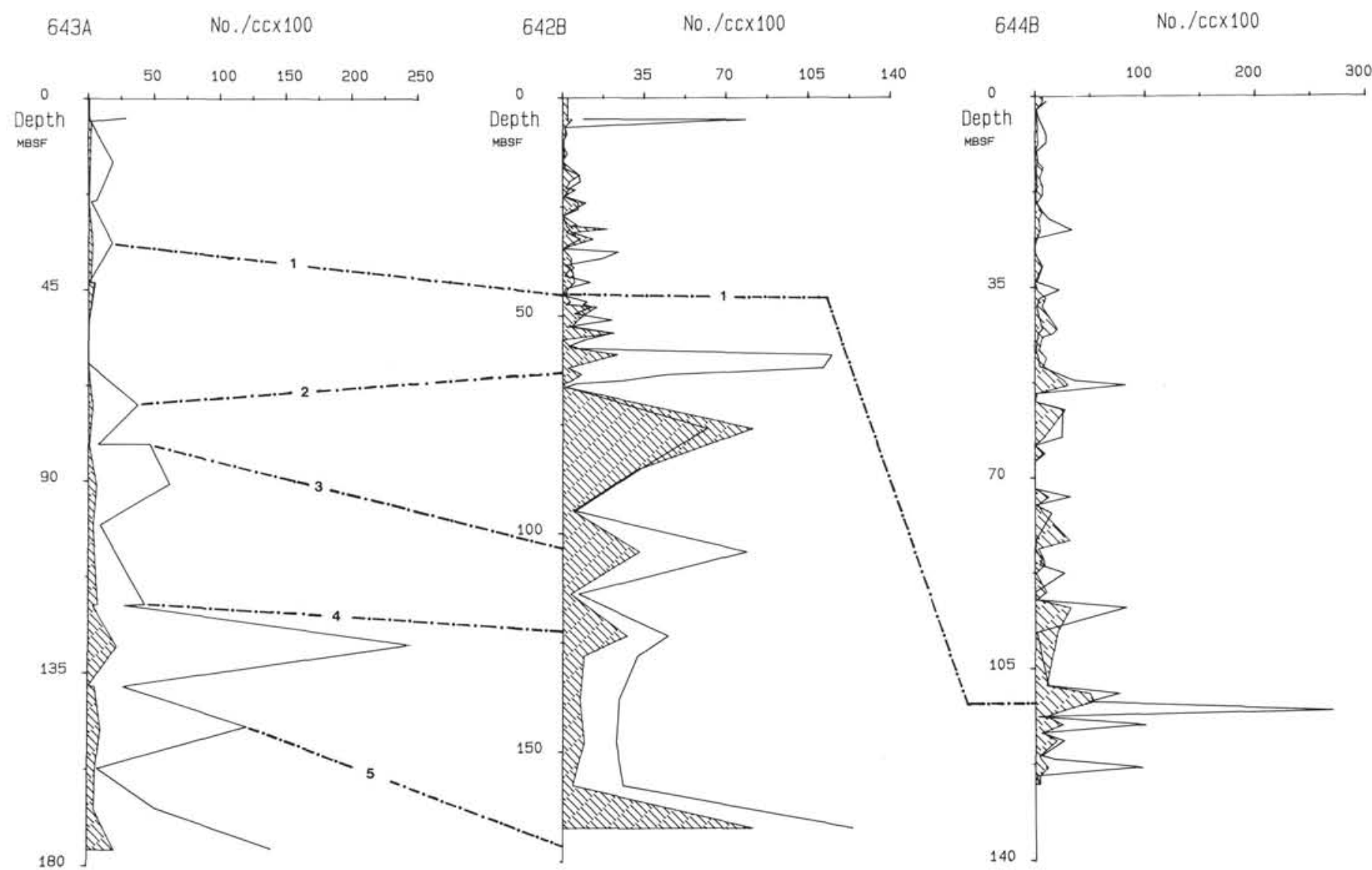

Figure 3. Graphs of fluctuations in concentrations of indigenous dinocysts (unshaded areas) and of pollen and spores (hatchured areas) for upper Cenozoic sediments from the outer (Site 643) to inner part (Site 644) of the Vøring Plateau. Dotted lines indicate chronostratigraphic correlations: (1) base of Jaramillo event; (2) Gauss/Gilbert boundary; (3) chron 8 base; (4) middle/late Miocene boundary; (5) early/middle Miocene boundary. Verti$\mathrm{cal}$ axis shows depth of meters below seafloor (msbf). Horizontal axis shows $1 / 100$ th of the number of palynomorphs per $\mathrm{cm}^{3} \mathrm{sediment}$.

observations that maximum dinocyst productivity occurs in neritic environments (Wall et al., 1977) and that pollen-spore deposition declines exponentially with distance offshore (Mudie, 1982).

\section{DINOCYST STRATIGRAPHY}

\section{Taxonomy and Zonation}

More than 100 late Cenozoic dinoflagellate and acritarch morphotypes were observed in the Leg 104 samples, of which about 50 may be new species. Many of these morphotypes require detailed study and comparison with similar forms illustrated by Manum (1976) and other workers (e.g., Powell, 1986 a, b, c; Wrenn and Kokinos, 1986; Matsuoka, 1983; Bujak and Matsuoka, 1986a). In this report, therefore, informal taxonomy is frequently used, and descriptions are confined to notes which explain how certain taxonomic problems have been treated in this report. Some of the new taxa which also occur in the Labrador Sea and/or Baffin Bay are described elsewhere (Head et al., in press a,b; de Vernal and Mudie, in press a, b). Not all bibliographic references are included here for taxa described before 1985 , but throughout the report, the nomenclature of Lentin and Williams (1985) is followed. That publication provides the necessary bibliography. The Appendix lists all the names and authors of the dinocysts and acritarchs referred to in this paper.

Wherever possible, the proposed zonation emphasizes previously well-documented species, with the zones being based on concurrent ranges of these index species. The proposed zona- tion may require some revision on completion of detailed taxonomic studies and chronostratigraphic correlation of the Leg 104 Sites (Goll, this volume). Similarity between the dinocyst zones described here and in previous studies of other high-latitude regions (Fig. 11) suggests, however, that the provisional biozones are approximately valid.

\section{Dinocyst Distribution: Site 642}

The most complete sequence of upper Miocene to Pleistocene sediments $(150 \mathrm{~m})$ was recovered from Holes $642 \mathrm{~B}$ and $642 \mathrm{C}$. Magnetostratigraphic data (Bleil, this volume) and planktonic foraminiferal distributions also provide relatively good time control for these holes (note that the revised time scale of Berggren et al., 1985 is used throughout the Leg 104 reports). Dinocysts were initially studied in 91 samples taken at 1-m intervals in cores from Holes 642A and 642B (Core 104-642A-1H and Cores $104-642 \mathrm{~B}-1 \mathrm{H}$ through $-8 \mathrm{H}$ ), and at 20 to $70-\mathrm{cm}$ intervals in Core 104-642C-11 of Hole 642C. Unfortunately, it only later become evident from postcruise biostratigraphic studies that the upper Miocene section lies below Cores 104-642B-9H and $-642 \mathrm{C}-11 \mathrm{H}$ in Holes $642 \mathrm{~B}$ and $642 \mathrm{C}$, respectively. In this study, therefore, only core-catcher samples could be examined from the upper Miocene sediments.

The distributions of the main late Cenozoic taxa are shown in Figure 5, and high-resolution data for the uppermost Miocene and lower Pliocene interval of Hole 642C are shown in Figure 6 . These new data, combined with detailed onshore studies 
644 A $1-9$

No./cc $\times 100$

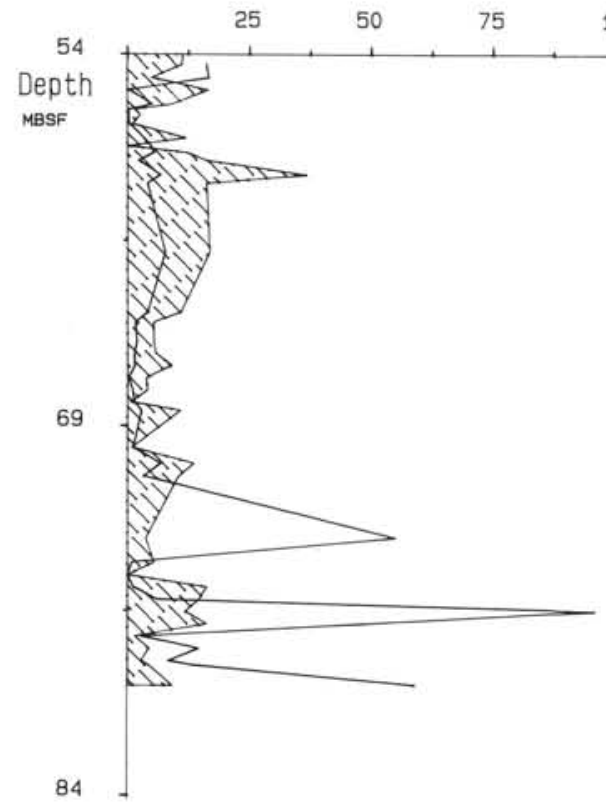

644A $10-34$

No./ $\operatorname{cc} \times 100$
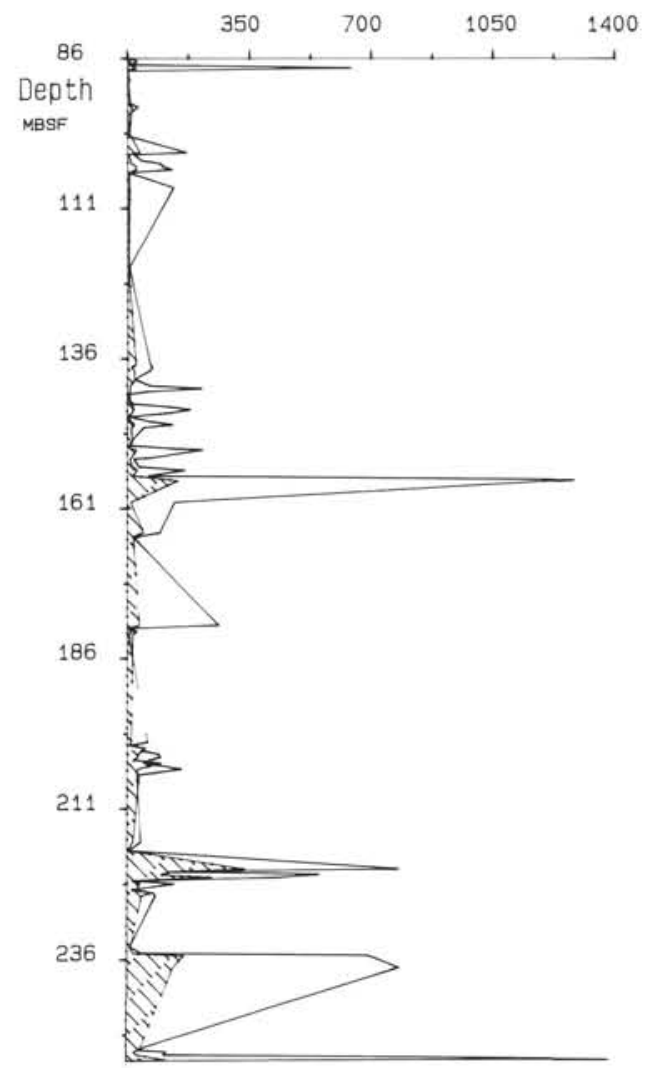

261
$642 \mathrm{C}$

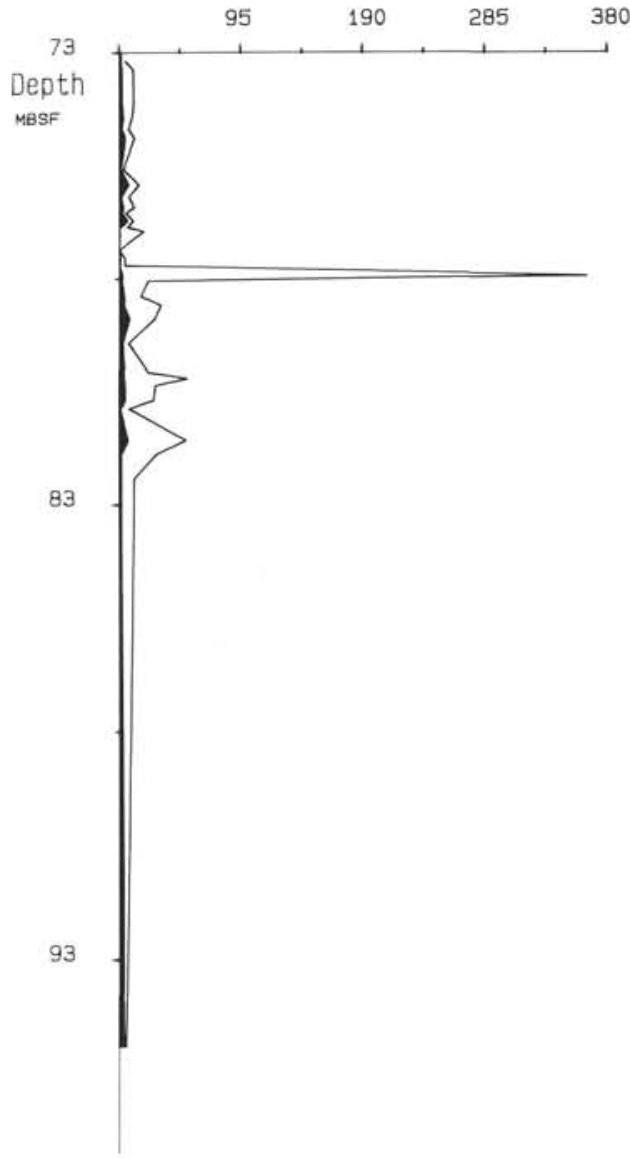

Figure 4. Graphs of fluctuations in concentrations of indigenous dinocyst (unshaded) and pollen and spores (hatchured) for very high-resolution sample intervals at Site 644 (upper Pliocene-upper Pleistocene) and for Site 642 (upper Miocene-middle Pliocene). Vertical scale: depth in meters below sea floor (mbsf). Horizontal scale: $1 / 100$ th number of palynomorphs per $\mathrm{cm}^{3}$ sediment. 

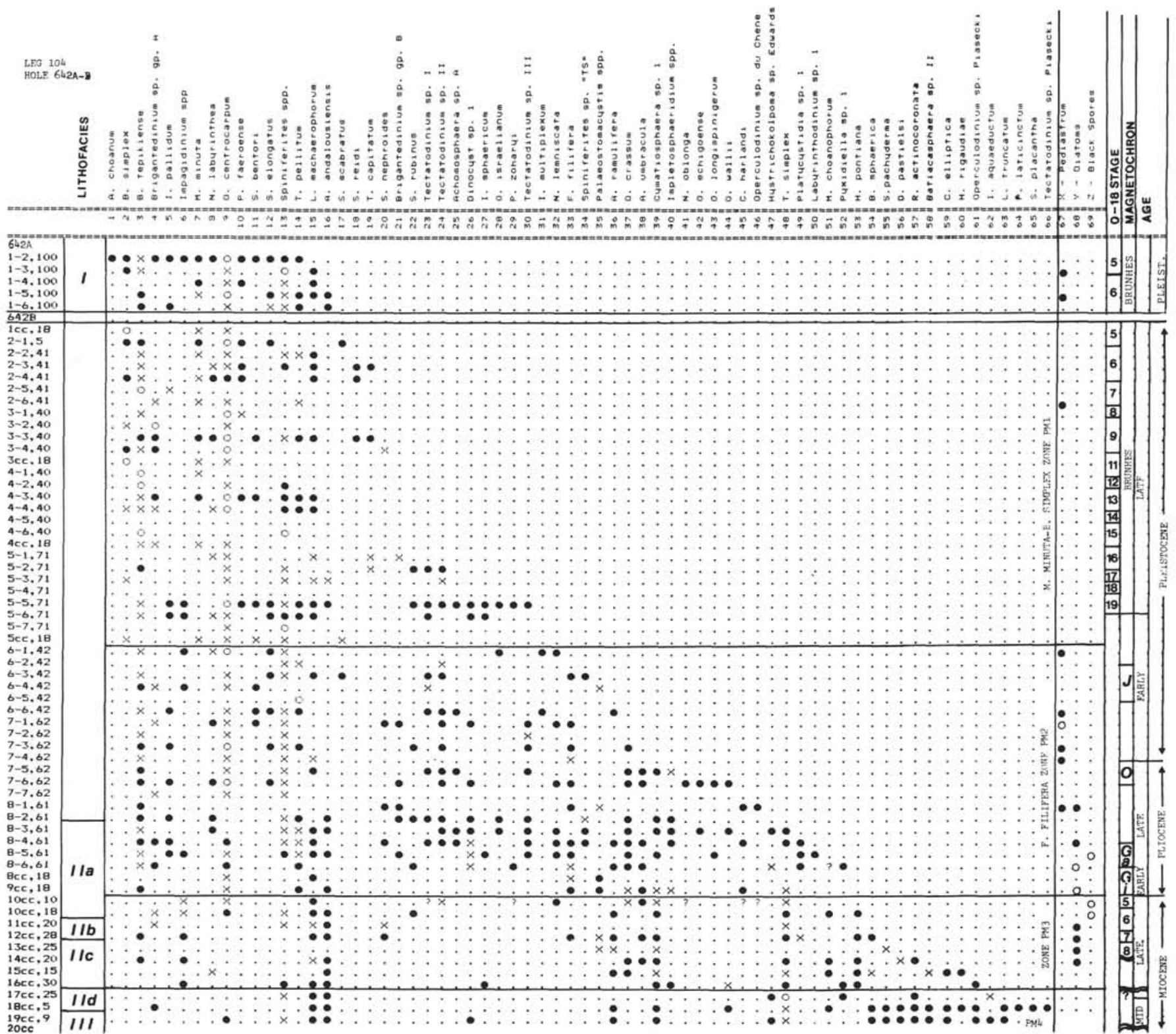

Figure 5. Range chart for selected dinocysts and acritarchs, Holes $642 \mathrm{~A}$ and $642 \mathrm{~B}$. Species are ordered by highest appearance and are listed by number of Appendix; relative abundances are indicated by: $\mathrm{O}=$ abundant $(>49 \%) ; \mathrm{X}=$ common $(10-49 \%) ; \bullet=$ rare to frequent $(1-9 \%) ; .=$ not present. Lithofacies are I-glacial mud; IA-dark glacial mud interbedded with foraminifer-nannofossil ooze; Ic-siliceous and nannofossil muds interbedded with dark glacial sand; IIa-siliceous nannofossil ooze and mud; IIb-siliceous mud or sandy mud and ooze; IIc-interbedded nannofossil/siliceous ooze and mud; IId-siliceous-calcareous ooze, siliceous mud and nannofossil ooze; III-diatom or siliceous mud and ooze. Wavy lines below magnetochron 8 indicate possible stratigraphic hiatuses.

of cyst morphologies, require that several changes to be made for the informal Zones PM1 to PM4 of the shipboard palynostratigraphy for Leg 104 (Eldholm, Thiede, Taylor, et al., 1987).

1. The top of Zone PM4 is now placed between Samples 104-642B-16H,CC, $30-32 \mathrm{~cm}$, and $-17 \mathrm{H}, \mathrm{CC}, 20-22 \mathrm{~cm}$, at the last appearance datum (LAD) of Impagidinium aquaeductum (=Nematosphaeropsis aquaeducta). Younger occurrences of poorly preserved $I$. aquaeductum cysts are now considered to be reworked. The base of Zone PM4 is provisionally placed at Sample 104-642B-19H,CC, $8-10 \mathrm{~cm}$, but it cannot be defined with certainty because of a possible hiatus in Core 104-642B-19H and poor recovery of cysts from Cores $104-642 \mathrm{~B}-20 \mathrm{H}$ to $-22 \mathrm{H}$.

2. The base of Zone PM3 is now extended to Sample 104$642 \mathrm{~B}-16 \mathrm{H}, \mathrm{CC}, 30-32 \mathrm{~cm}$, which corresponds to the first ap- pearance datum (FAD) of Hystrichosphaeropsis ?pontiana (this taxon was included with $H$. obscura in the shipboard study). The top of Zone PM3 is marked by the last common occurrence of Amiculosphaera umbracula. This boundary is placed in Sample 104-642B-9H,CC of Hole 642B and in Sample 104-642C$11 \mathrm{H}-3,56-58 \mathrm{~cm}$ of Hole $642 \mathrm{C}$. The provisional name of Zone PM3 is now changed to the Achomosphaera andalousiensis acme zone.

3. The base of Zone PM2 is still located at Sample 104$642 \mathrm{~B}-9 \mathrm{H}, \mathrm{CC}$, but it is redefined as being marked by the FAD of Filisphaera filifera and Tectatodinium pellitum. The top of Zone PM2 is now relocated at Sample 104-642B-6H-lG, 42-44 cm, which marks the LAD of Nematosphaeropsis lemniscata. Zone PM2 now contains the range of $F$. filifera and is therefore renamed the $F$. filifera zone. 


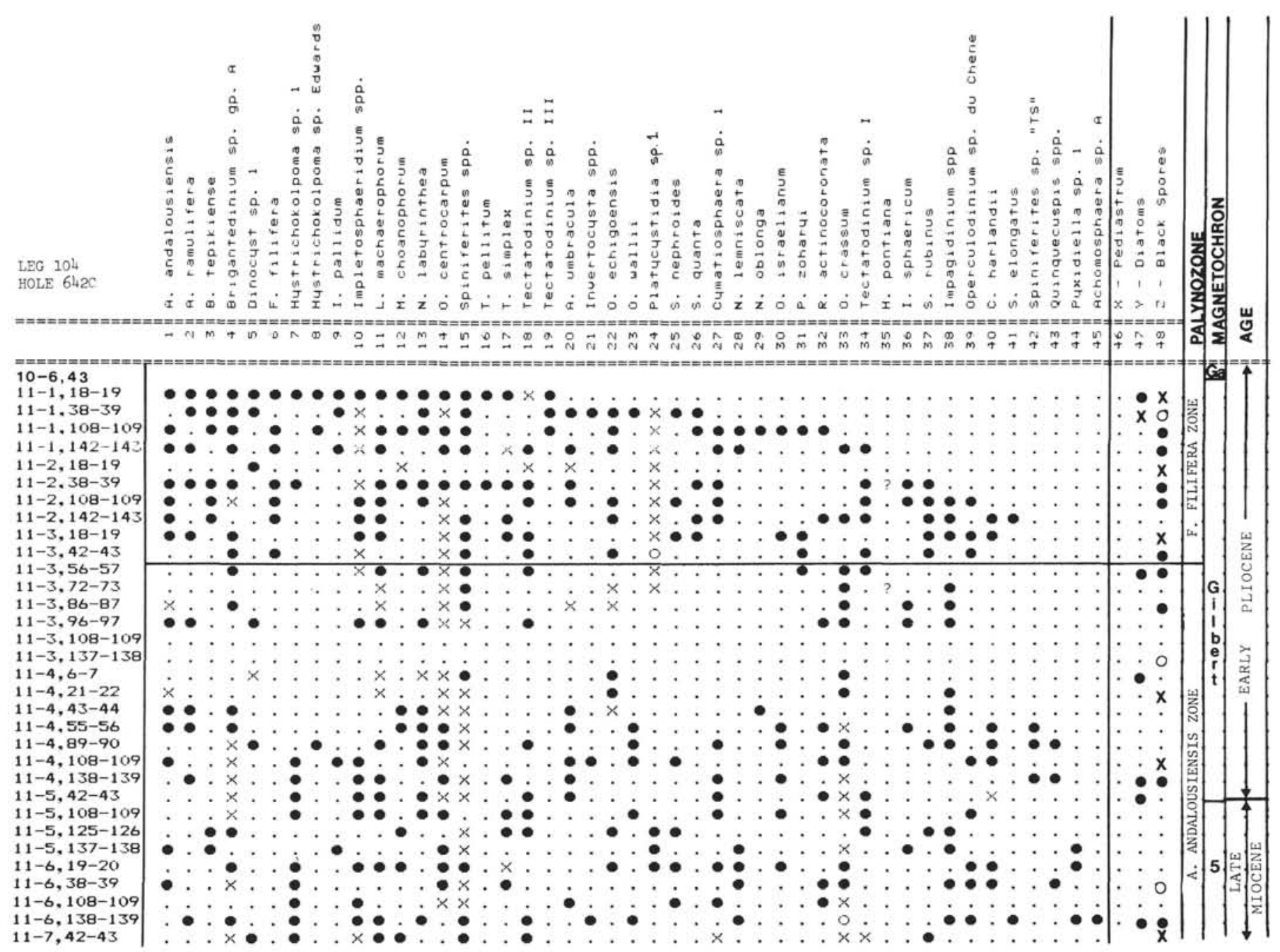

Figure 6 . Range chart for selected dinocysts and acritarchs, Site 642 , Core $104-642 \mathrm{C}-11 \mathrm{H}$. Species are ordered by highest appearance and are listed by number in Appendix; relative abundances are as in Figure 5.

4. Core 104-642C-11H contains the upper half of Zone PM3 and the lower part of Zone PM2, with the boundary being placed at the FAD of $F$. filifera in Sample 104-642C-11H-3, 42$44 \mathrm{~cm}$.

5. Zone PM1 now extends from Sample 104-642B-5H,CC, $12-15 \mathrm{~cm}$ to the highest samples examined at Site 642 , including Hole 642A from Sample 104-642A-1H-2, 100-102 cm to $-1 \mathrm{H}-6$, $100-102 \mathrm{~cm}$. The base of the zone is marked by the FAD of Multispinula minuta and Brigantedinium simplex, and includes the ranges of these species, from which it is now renamed.

\section{Dinocyst Distribution: Site 643}

For this study, only 23 core-catcher samples were examined from Hole 643A (Fig. 7), and postcruise studies have shown that several stratigraphic hiatuses of 1 to $6 \mathrm{~m}$.y. duration disrupt the biostratigraphic sequence (Goll, this volume). Consequently, a precise zonation is not possible for this hole. Using the same criteria as described above for Site 642 , however, the following revisions have been made of the shipboard palynostratigraphy (Eldholm, Thiede, Taylor, et al., 1987).

1. Zone PM4/5 (104-643A-19H,CC to $-11 \mathrm{H}, \mathrm{CC})$ is now assigned to two provisional zones, PM5 and PM4. The top of Zone PM5 is placed at Sample 104-643A-14H,CC, 10-12 cm, which corresponds to the LAD of a new cyst form, ?Thalas- siphora sp. cf. Th. pansa. The base of this zone is incompletely defined due to lack of high-resolution sampling. The LAD of Palaeocystodinium golzowense and ?Evittosphaerula sp. 1 occur at Sample 104-643A-17H,CC, 30-40 cm and Zone PM5 contains the LAD of Emslandia spiridoides (=Apteodinium spiridoides), after which is is now renamed. Zone PM4 extends from Sample 104-643A-14H,CC, $10-12 \mathrm{~cm}$ to $-10 \mathrm{H}, \mathrm{CC}, 5-7 \mathrm{~cm}$. The base of this zone is marked by the FAD of I. aquaeductum, Labyrinthodinium truncatum and Cyclopsiella elliptica. As at Site 642 , the top of this zone is marked by the LAD of $I$. aquaeductum.

2. Samples $104-643 \mathrm{~A}-11 \mathrm{H}, \mathrm{CC}$ to $-9 \mathrm{H}, \mathrm{CC}$ are now reassigned to Zone PM3, based on the acme of $A$. andalousiensis, the LAD of $H$. obscura, and the occurrence of $A$. umbracula. It should be noted, however, that the nominal top of this zone at Sample $104-643 \mathrm{~A}-8 \mathrm{H}, \mathrm{CC}, 28-30 \mathrm{~cm}$ is poorly delineated because of a hiatus between Samples 104-643A-8H and $-9 \mathrm{H}$, and because of a barren interval between Samples 104-643A-8H,CC and $-643 \mathrm{~A}-7 \mathrm{H}, \mathrm{CC}, 7-9 \mathrm{~cm}$.

3. Zone PM2/3 (104-643A-5H,CC to $-3 \mathrm{H}, \mathrm{CC})$ and the underlying barren interval shown in the shipboard report are now replaced by Zone PM2, which extends from Sample 104-643A$7 \mathrm{H}, \mathrm{CC}, 7-9 \mathrm{~cm}$ to $-4 \mathrm{H}, \mathrm{CC}, 9-11 \mathrm{~cm}$ and is marked by the first and last occurrences of $F$. filifera. The samples from 104-643A$3 \mathrm{H}, \mathrm{CC}$ to the top of the hole remain in Zone PM1. 


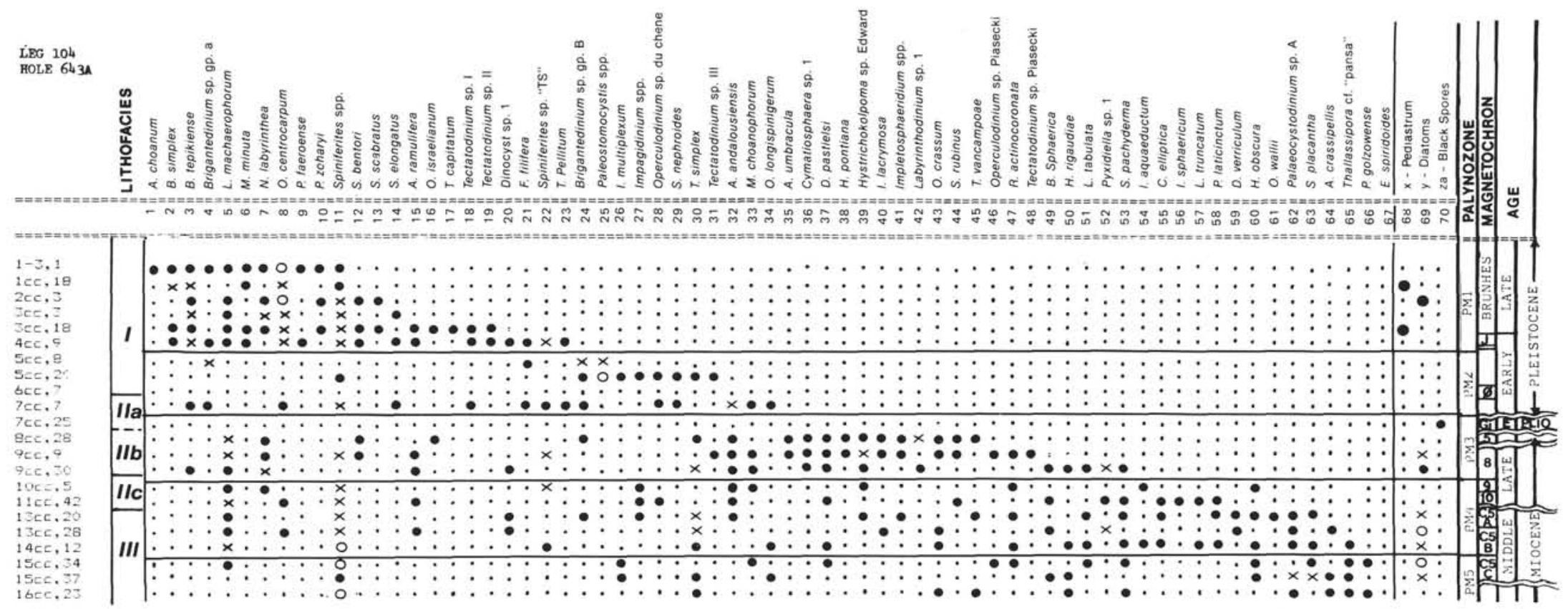

Figure 7. Range chart for selected dinocysts and acritarchs, Hole 643A. Species are ordered by highest appearance and are listed by number in Appendix; relative abundances and lithofacies are as in Figure 5. Wavy lines on right indicate probable stratigraphic hiatuses. 


\section{Dinocyst Distribution: Site 644}

For this study, 200 samples from core intervals of $40-\mathrm{cm}$ spacing were examined from the base (upper Pliocene) to top (upper Pleistocene) of Hole 644A. Figures 8 and 9 show dinocyst distributions for most of these samples, excluding the top seven cores which are well represented by data for Hole 644B. A total of 65 samples from $100-\mathrm{cm}$ intervals were examined from the Pleistocene sediments cored in Hole 644B (Fig. 10). Both holes recovered continuous sequences of sediments for which biostratigraphic and magnetostratigraphic data apparently provide good age control (Goll, and Bleil, this volume). According to the revised palynozonation described above for Hole 642B, several changes have been made to update the shipboard palynostratigraphy for Site 644 .

1. Zone PM3 is no longer recognized in Hole 644A. The refined stratigraphy for Site 642 now clearly shows that the ranges of several common late Miocene species, e.g., A. umbracula and Operculodinium crassum, continue upwards in Zone PM2 to at least the Pliocene/Pleistocene boundary. Small numbers of other species with more restricted occurrences in Zone PM3 at Site 642, e.g., Corrudinium harlandi, Tectatodinium simplex, and Reticulatosphaera actinocoronata, occur rarely and sporadically in the upper Pliocene interval of Hole 644A, and they are probably reworked. The occurrence of $A$. andalousiensis is also sporadic in Pleistocene sediments of high-latitude North Atlantic regions (Asku et al., in press), whereas coherent assemblages of late Miocene and Pliocene index species were not found at Site 644

2. The base of Hole 644A contains Zone PM2; the zone top occurs at Sample 104-644A-10H-3, 35-37 cm, which marks the LAD of $N$. lemniscata and the FAD of $M$. minuta and B. simplex. Zone PM1 extends from this sample to the top of the hole.

3. In Hole 644B, Zone PM2 extends from the base to Sample 104-644B-10H-5, $86-88 \mathrm{~cm}$, which lies just above the LAD of $N$. lemniscata and contains the FAD of $M$. minuta and $B$. simplex. Zone PM1 extends from this sample to the top of the hole.

\section{Provisional Norwegian Sea Zonation and Correlation}

\section{Impagidinium aquaeductum-Zone PM4}

This is the oldest Miocene palynozone that can be delimited with reasonable certainty from the samples in this study. As defined here, the base of Zone PM4 is marked by the FAD of $\mathrm{La}$ byrinthodinium truncatum and Cyclopsiella elliptica, and by the LAD of Palaeocystodinium golzowense and a new cyst form, Thalassiphora sp. cf. Th. pansa, which is common together with Emslandia spiridoides in the underlying early Miocene Zone PM5 (=Emslandia spiridoides Zone). The top of Zone PM4 is defined as the LAD of $I$. aquaeductum. In both Holes 642B and $643 \mathrm{~A}$, three well-known middle Miocene and older species have their LAD just below the zone top: L. truncatum, Pentadinium laticinctum, and Systematophora placacantha. Other characteristic species of Zone PM4 include Operculodinium sp. of Piasecki (1980), O. wallii, Hystrichokolpoma rigaudiae, $\mathrm{Ba}$ tiacasphaera sphaerica, and cf. Batiacasphaera sp. II of Edwards (1984), Spiniferites sp. cf. S. pachyderma, Dapsilidinium pastielsii, Reticulatosphaera actinocoronata, Tectatodinium simplex, and Lingulodinium machaerophorum. Spiniferites species (i.e., various undifferentiated taxa, excluding those listed separately on the range charts) are particularly abundant and diverse in this zone and they will require detailed study to determine their taxonomy and stratigraphic value. In the lower section of Zone PM4 (represented only at Site 643 in this study), cf. Achomos- phaera crassipellis, Dinopterygium verriculum (= Heteraulacacysta verricula) and Palaeocystodinium sp. A of Costa and Downie (1979) are common.

The age of the Zone PM4 boundaries are presently not very well constrained due to the paucity of calcareous microfossils and apparent presence of hiatuses between Cores 104-643A-13H and $-11 \mathrm{H}$, and two hiatuses between Cores 104-642B-20H and $-13 \mathrm{H}$ (Bleil, this volume and Goll, this volume). The base of Zone PM4 in Hole 643A, however, lies above the planktonic foraminifer Zone N4-6 (early Miocene, ca. 17.5-23.5 Ma) and occurs just above the base of magnetochron C5B (16.22 Ma) in Hole 642B. The top of Zone PM4, both Holes 643A and 642B, occurs in the middle of foraminifer Zone 16 which gives it an age of about $9 \mathrm{Ma}$. These constraints indicate a middle to early late Miocene age for the zone. Most of the species listed above for Zone PM4 are common throughout all or part of the middle to lowermost upper Miocene sediments of DSDP Leg 81, Hole 555 , on Rockall Bank (Edwards, 1984), the Langhian to Serravallian dinocyst zones LAN-5 to LAN-8 in Italy (Powell, 1986a), and the $L$. truncatum to $D$. verriculum zones of the Gram Section in Denmark (Piasecki, 1980). An age of late Langhian (15.6 Ma) to early Tortonian (9 Ma) for this Norwegian Sea dinocyst zone is therefore broadly consistent with the North Atlantic middle Miocene zonation (see Powell, 1986a). A significant difference, however, is found in the younger age of the LAD for I. aquaeductum, which has an early Tortonian LAD at both Sites 642 and 643 on the Vøring Plateau. This discrepancy may be due to the sedimentary hiatuses at these sites, which might facilitate upward mixing of sediment across erosional surfaces. It is notable, however, that the top of Zone PM4 is approximately the same age as that of Dinocyst Zone 1a at DSDP Site 611 (Mudie, 1986) in the subpolar region of the eastern North Atlantic, although the marker species of Zone 1a differ from those in Zone PM4 and do not include I. aquaeductum or L. truncatum (see Head et al., in press a, b). The similar age of the zone tops suggests that a regional overturn of dinocyst species took place in the high-latitude North Atlantic seas during the early late Miocene.

\section{Achomosphaera andalousiensis-Zone PM3.}

This zone is presently best defined by the acme of $A$. andalousiensis and the FAD of Amiculosphaera umbracula which occurs just above the base of the zone in Holes 643A and 642B. The basal zone boundary is presently not clearly definable because of the lack of high-resolution sampling for these holes; high-resolution data for core $104-642 \mathrm{C}-11 \mathrm{H}$, however, provides detailed information for the zone top. The base of Zone PM3 contains the FAD of Hystrichosphaeropsis ?pontiana which probably has its range within this zone (isolated occurrences above the top of Chron 5 in Hole $642 \mathrm{C}$ are probably reworked). Impagidinium sphaericum also has its FAD at the zone base. At Site 642, Operculodinium crassum has its FAD just above the zone base, Bitectatodinium tepikiense has its FAD in the same sample as A. umbracula, and Selenopemphix sp. B of Powell (1986b) has its FAD in the middle of the zone. Several common middle Miocene taxa have their LAD between the base and middle of the zone, including Operculodinium sp. of Piasecki (1980), H. rigaudiae, Cyclopsiella elliptica, Batiacasphaera sp. II of Edwards (1984), B. sphaerica., and Dapsilidinium pastielsii. The top part of Zone PM3 is marked by the FAD of Nematosphaeropsis lemniscata, Spiniferites rubinus, Corrudinium harlandi, Operculodinium sp. of Jan du Chêne (1977), Tectatodinium sp. I, and Tectatodinium sp. II. Other taxa which are common in all or part of Zone PM3 include Melitasphaeridium choanophorum, Tectatodinium simplex, Dinocyst $\mathrm{sp}$. 1. The cyst forms referred to as Hystrichokolpoma sp. 1, Platycystidia sp. 1, and Imple- 
LEG 104

HOLE $644 A$,
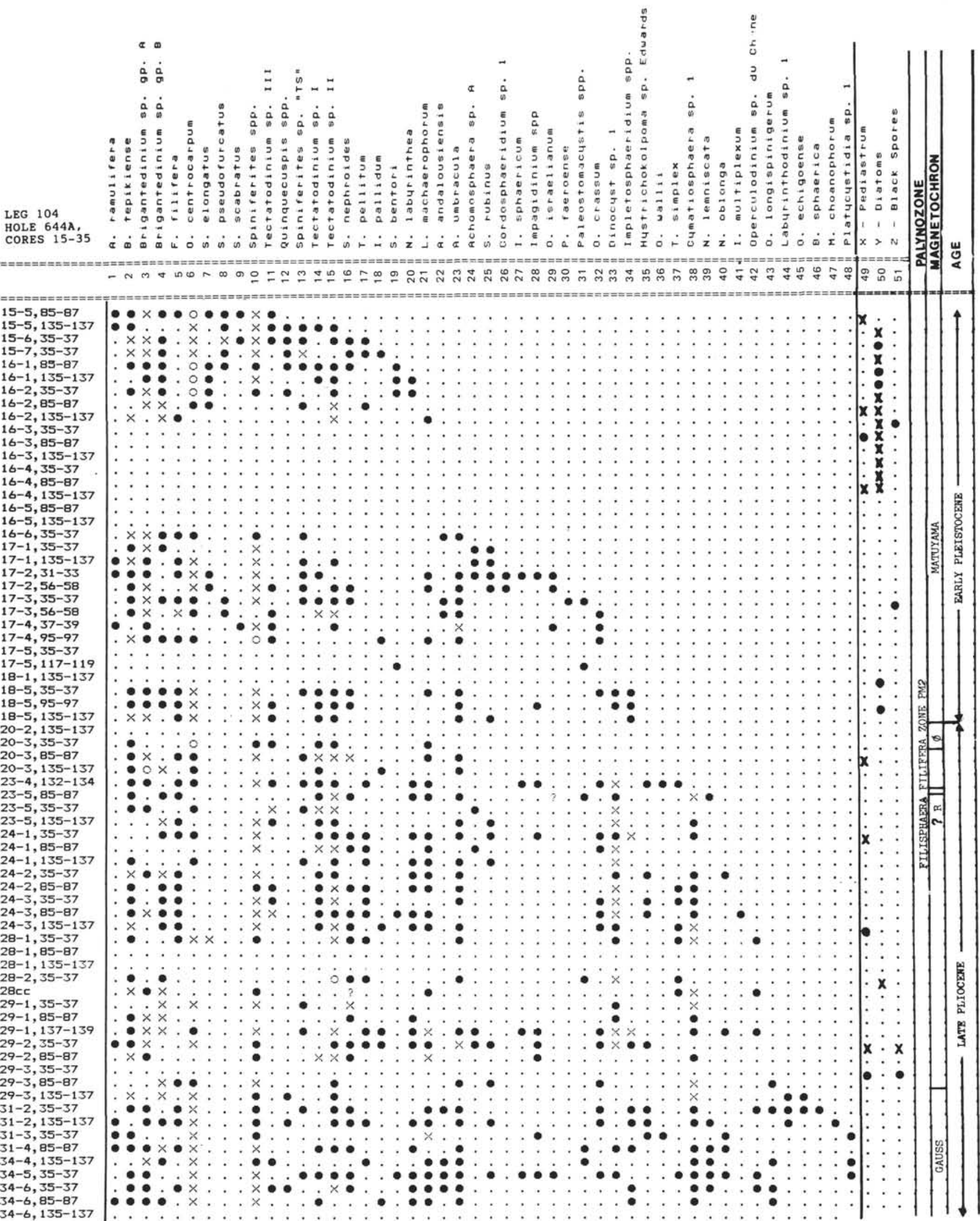

Figure 8. Range charts for selected dinocysts and acritarchs, Hole 644A, upper Pliocene to lower Pleistocene. Species are ordered by highest appearance; graphic relative abundances and lithofacies symbols are as in Figure 5. 


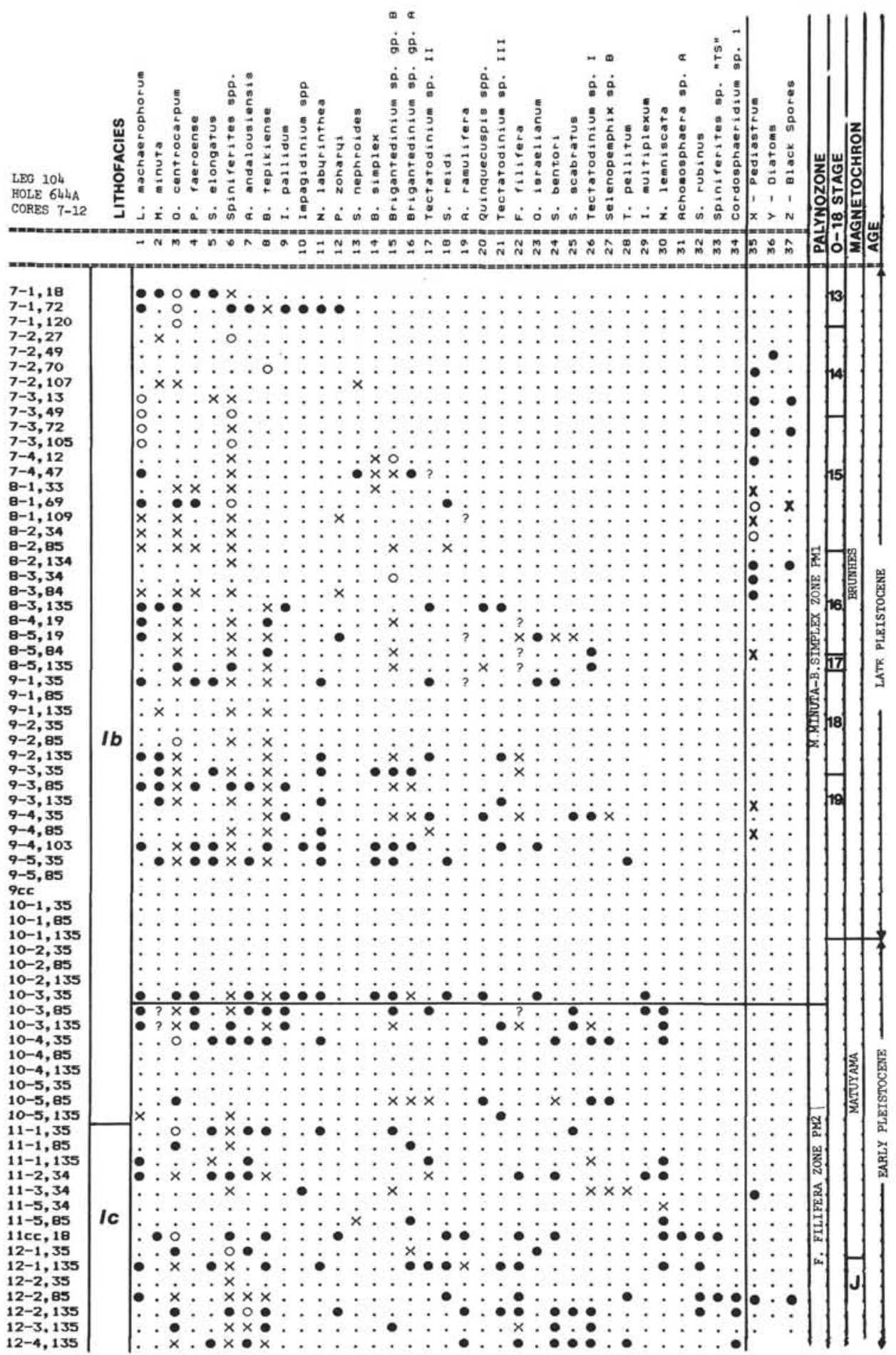

Figure 9. Range charts for selected dinocysts and acritarchs, Hole 644A, Pleistocene. Species are ordered by highest appearance; graphic relative abundances and lithofacies are as in Figure 5.

tosphaeridium spp. in Mudie (1986) are common, along with two small cyst forms, Cymatiosphaera sp. 1 and ?Labyrinthodinium sp., which are incorrectly referred to Labyrinthodinium truncatum and ?Nematosphaeropsis aquaeducta in Mudie (1986). All of these small cyst forms are now referable to acritarch taxa (Head et al., in press a, b; de Vernal and Mudie, in press a).

According to the biochronology and magnetostratigraphy of Goll (this volume), the age of dinocyst Zone PM3 extends from about $9 \mathrm{Ma}$ to the middle of the Gilbert magnetochron, at about 4.2 Ma. The zone therefore includes most of the late Mio- cene Tortonian Stage, all of the Messinian Stage, and the early part of the early Pliocene Zanclean Stage (Fig. 11). The distribution and species composition of dinocyst assemblages in Zone PM3 closely resemble those found in dinocyst Zone 1b at DSDP Site 611 on the Gardar Ridge south of Iceland (Mudie, 1986), which has an age of ca. 9.5 to $4.1 \mathrm{Ma}$, and similar assemblages are found in Zone IIb of DSDP Site 400 in the Bay of Biscay (Harland, 1979) which has an age of 10.2 to $4 \mathrm{Ma}$. The assemblages in Zone PM3 are also similar to those in the Andalousian Stage sediments at Carmona (Jan du Chêne, 1977) which have an age of ca. 10 to $3.4 \mathrm{Ma}$. In contrast, only about half as many 


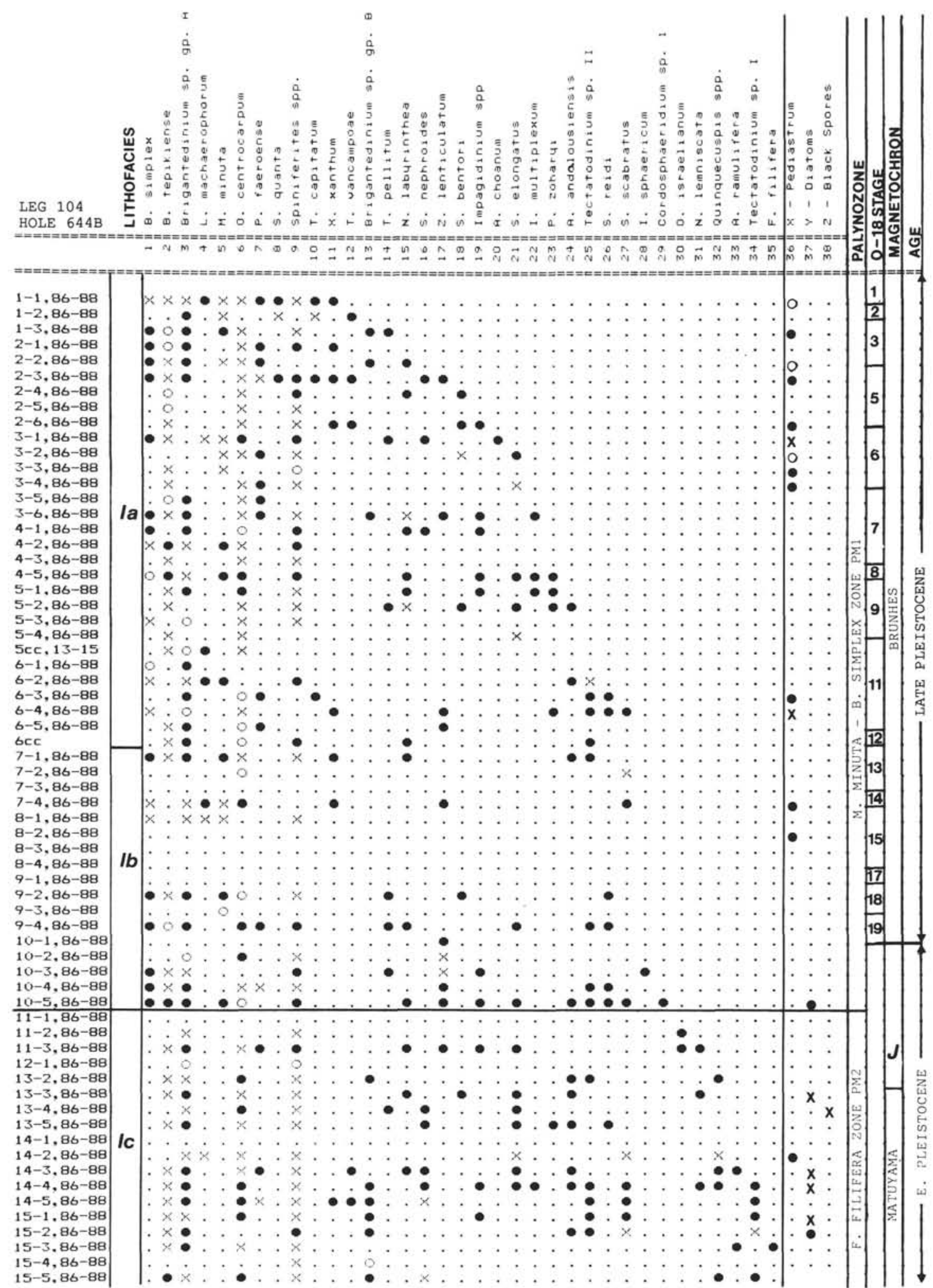

Figure 10. Range chart for selected dinocysts and acritarchs, Hole 644B. Species are ordered by highest appearance; relative abundances and lithofacies symbols are as in Figure 6.

dinocyst species occur in Zone PM3 as were reported for the Castellanian superstage (Tortonian and Messinian) section in Italy (Powell, 1986b). Part of this difference may reflect the lower resolution sampling for the high-latitude deep-sea sites. For ex- ample, C. harlandi, Impagidinium pallidum, Operculodinium sp. of Jan du Chêne (1977), and Invertocysta lacrymosa were not found in Hole 642B but they were found in several samples from Core $104-642 \mathrm{C}-11 \mathrm{H}$. More detailed sampling is therefore 


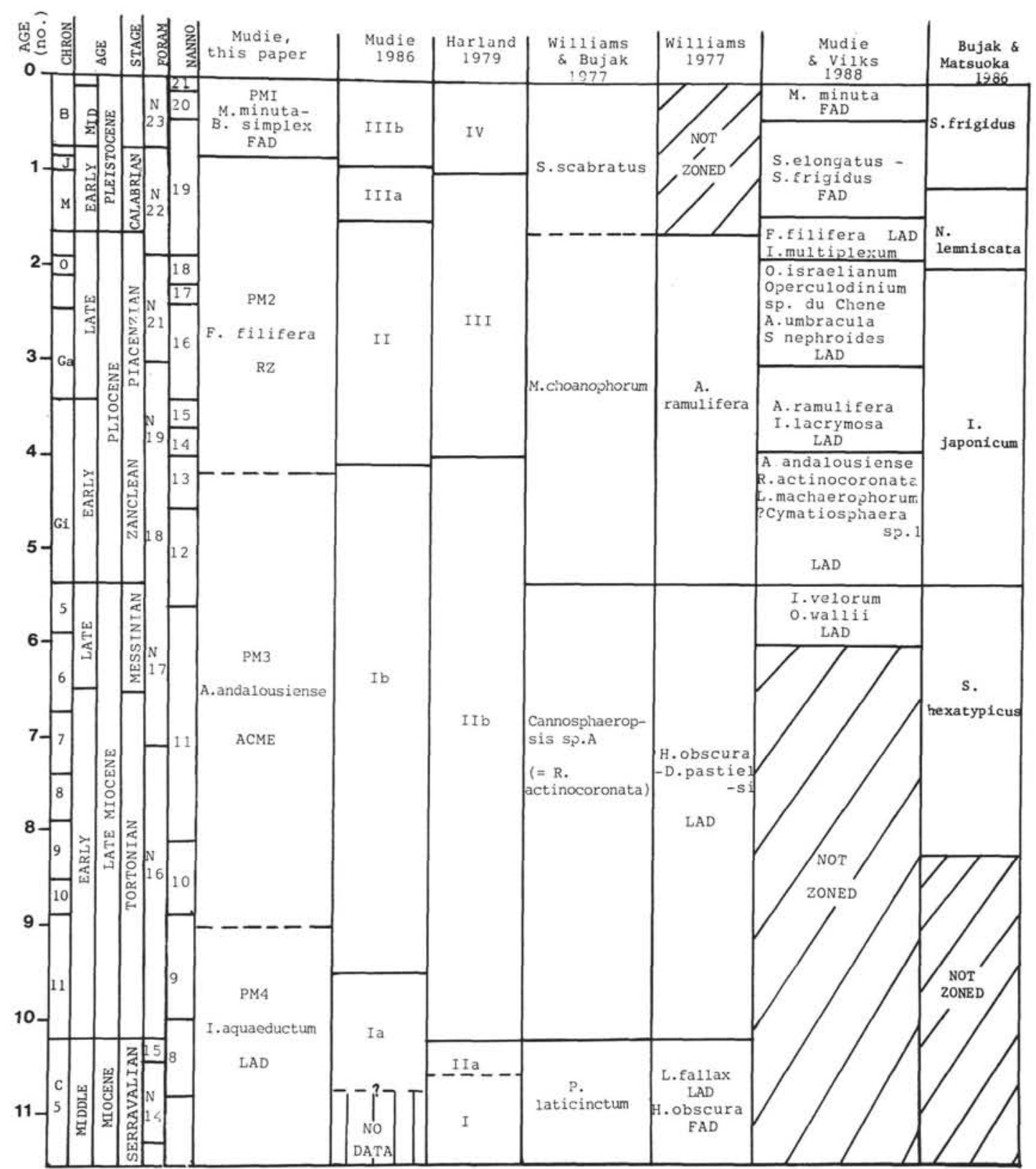

Figure 11. Correlation chart showing the chronostratigraphic relation between the provisional Leg 104 dinocyst zonation and zonations at DSDP Site 611 (Mudie, 1986), Site 400 (Harland, 1979), eastern Canadian offshore wells (Williams and Bujak, 1977; Williams, 1977), northwestern North Atlantic Ocean (Mudie and Vilks, 1988), and the North Pacific Ocean (Bujak and Matsuoka, $1986 \mathrm{a}, \mathrm{b}$ ). FORAM = foraminifer Zone; NANNO = nannofossil Zone; CHRON indicates magnetochronology, where $\mathrm{B}=$ Brunhes, $\mathrm{J}=$ Jaramillo, $\mathrm{M}=$ Matuyama, $\mathrm{O}=$ Olduvai, $\mathrm{Ga}=$ Gauss, $\mathrm{Gi}=$ Gilbert event.

required to refine the zonation for the upper Miocene interval of the Norwegian Sea.

\section{Filisphaera filifera-Zone PM2.}

This zone is presently defined primarily by the range of $F$. filifera and by the partial range of $N$. lemniscata, which has its LAD at the top of the zone. In Holes 642B and 643A the base of the zone is clearly marked by the FAD of $F$. filifera and Tectatodinium pellitum; in Hole $642 \mathrm{C}$ the FAD of $T$. pellitum occurs about one meter above the FAD of $F$. filifera. Overall, the assemblages in Zone PM2 are dominated by Operculodinium centrocarpum (which first becomes abundant just above the base of this zone), B. tepikiense, Tectatodinium sp. I and sp. II, Spiniferites ramosus, $S$. membranaceus, and $S$. mirabilis). Brigante- dinium species group A (undifferentiated, thick-walled, dark brown morphotypes, excluding $B$. simplex) and Brigantedinium species group B (thin-walled morphotypes) also become common in this zone. Species diversity, measured as total number of species $(\mathrm{S})$ is relatively high $(\mathrm{S}=16-26)$ in the lower half of the zone below the Olduvai magnetochron $(1.88 \mathrm{Ma})$ but it decreases sharply $(S=6-12)$ in the upper part. The age of Zone PM2 is well constrained by magnetostratigraphic data which show that the zone extends from the middle of the early Pliocene (ca. 4.2 $\mathrm{Ma}$ ) to the top of the early Pleistocene, between the Jaramillo and Brunhes magnetochrons (ca. 0.8 Ma).

The base of Zone PM2 includes most of the dinocyst and acritarch species found at the top of Zone PM3, but between the Gauss magnetochron (3.4 Ma) and the top of the Olduvai 
event all the small acritarchs disappear, and seven dinocyst species have their LAD in Hole 642B: $M$. choanophorum, $C$. harlandi, T. simplex, Operculodinium sp. of Jan du Chêne (1977), O. wallii, O. echigoense, and Nematosphaeropsis oblonga (Mudie, 1986). It is also notable that $A$. andalousiensis disappears at, or just above, the Gauss magnetochron at all the Vøring Plateau sites, but it reappears for brief intervals during the Pleistocene at Sites 642 and 644. The upper part of Zone PM2 is marked by the LAD of $O$. crassum and $A$. umbracula just above the Pliocene/Pleistocene boundary. Spiniferites elongatus and the cyst-form of Peridinium faeroense (Dale, 1977) have their FAD at this boundary in Holes 642B and 644A; $S$. scabratus and Impagidinium multiplexum have their FAD at or just below the top of the zone.

In general, the composition and distribution of dinocyst assemblages in Zone PM2 are very similar to those observed in dinocyst Zones II and IIIa at DSDP Site 611, where most of the species listed above show a similar succession and age for the LADs and FADs (Mudie, 1986). The assemblages in Zone PM2 are also comparable to those in Zone III at DSDP Site 400 (Harland, 1979) and there is a notable similarity in the ages of the LADs for $M$. choanophorum, $C$. harlandi, $T$. simplex, $O$. crassum, and A. umbracula at all the North Atlantic sites from the Bay of Biscay to Vøring Plateau. The FAD of S. elongatus and $I$. multiplexum also have similar ages at Site 611 and the Vøring Plateau, but Harland (1979) reports a younger LAD (middle Pleistocene) for $S$. elongatus at Site 400, while Bujak and Matsuoka (1986a) report a late Miocene FAD for $S$. elongatus in the North Pacific. At present, no subdivision is made for Zone PM2, but future studies may warrant a division at the Pliocene/Pleistocene boundary to delimit an early Pleistocene subzone characterized by the FAD of S. scabratus and I. multiplexum and by the LAD of $N$. lemniscata. This subzone would then be comparable to the $N$. lemniscata zone in the North Pacific (Bujak and Matsuoka, 1986a).

\section{Multispinula minuta-Brigantedinium simplex-Zone PM1.}

This zone is delimited by the ranges of $M$. minuta and $B$. simplex which have their FAD at the zone base, at or just above the LAD of $N$. lemniscata. Peridinium faeroense cyst-form of Dale (1977) is commonly present throughout this zone. Other characteristic species are $S$. elongatus (here including $S$. frigidus and intergrades), $S$. scabratus, Impagidinium pallidum, $T$. pellitum, Trinovantedinium capitatum, Stelladinium reidi, and Selenopemphix nephroides, but their occurrences are often sporadic and their distribution within Zone PM1 varies largely with sampling density. In general, dinocyst assemblages in Zone PM1 are dominated by $O$. centrocarpum, B. tepikiense, and Brigantedinium spp. At all of the Vøring Plateau sites, however, there is a notable decrease in species diversity from the base to the middle of the zone, and at Sites 642 and 644 the LAD of the Tectatodinium sp. I, II, and III, Operculodinium israelianum, and Polysphaeridium zoharyi occurs in this interval, between the Brunhes/Matuyama boundary $(0.73 \mathrm{Ma})$ and the middle part of the late Pleistocene (isotopic stage 8, ca. $0.44 \mathrm{Ma}$ ). In contrast to the disappearance of these gonyaulacoid taxa, the diversity of protoperidinioid species increases during the late Pleistocene. This part of Zone PM1 includes the FAD of $T$. capitatum, Selenopemphix quanta, and at Site 644, Brigantedinium species group A (including B. cariacoensis, B. auranteum, and other indeterminate thick-walled round, brown protoperidinioid cysts).

\section{PALEOENVIRONMENTAL INTERPRETATION}

At present, few definite statements can be made about the paleoenvironmental significance of dinocyst assemblages from deep-sea locations because of conflicting views concerning their probable sources as indigenous phytoplankton vs. current-transported particles (Dale, 1986). A few outstanding features that have been observed elsewhere in the North Atlantic nonetheless appear worthy of comment.

1. The high total diversity of dinocyst species $(S>22)$ in Zones PM5 and PM4, combined with the abundance of Tuberculodinium vancampoae, large number of Spiniferites species, common Impagidinium species, and the presence of many large cyst-forms with inflated periphragms or processes appear to be typical features of lower to middle Miocene sediments in the North Atlantic region and to be indicative of warm (subtropical), saline $(>3.4 \%$ ) surface waters (Harland, 1983; Wrenn and Kokinos, 1986). If the Iceland-Faroe Ridge was indeed very shallow or emergent during the earlier Miocene (Eldholm, Thiede, and Taylor, this volume), the inflow of subtropical water would have been very restricted. The warm water dinocysts thus suggests that the inflow of a large volume of cold arctic water to the Norwegian-Greenland Sea had not yet commenced, so that the relatively small volume of warm North Atlantic surface water could have a strong effect on the climate of the region.

2. Seven middle Miocene dinocyst species with widespread distributions in the North Atlantic (I. aquaeductum, L. truncatum, C. ellipticum, $P$. laticinctum, $H$. obscura, $S$. placacantha, and $D$. pastielsii) disappear in Zone PM3 prior to the Tortonian/Messinian boundary at $6.5 \mathrm{Ma}$. This attrition is contrary to the supposed subsidence of the Iceland-Faeroe Ridge by 10 Ma which should have increased the inflow of North Atlantic water, thereby maintaining the warm surface water and introducing more North Atlantic species rather than eliminating species. Furthermore, a similar attrition of species is seen at DSDP Site 611 south of Iceland (Mudie, 1986), and it is believed that this widespread extinction may reflect the early stages of highlatitude climatic cooling, as found in eastern Iceland pollen studies (Mudie and Helgason, 1983).

3. Although total species diversity remains relatively high $(\mathrm{S}=16-26)$ in the uppermost Miocene and lower Pliocene intervals at the Vøring Plateau, the most abundant palynomorphs are often small acritarchs of uncertain botanical origin (Impletosphaeridium spp., Platycystidia, and ?Cymatiosphaera). At the Vøring Plateau and central North Atlantic sites from Iceland to the Azores (Mudie, 1986), these small cyst-forms are associated with abundant diatoms and/or black spores. It is thus possible that these acritarchs are organic walled resting spores of marine algae, e.g., Chrysomonads or Archeomonads. It is also notable that dinocyst abundance in these samples is often lower in the presence of abundant diatoms. This may reflect the fact that diatoms are more efficient users of inorganic nutrients; hence, they suppress growth of dinoflagellates when light and nutrients are not limiting growth factors.

4. It is notable that three common oceanic subarctic North Pacific dinocysts, F. filifera, N. lemniscata, and I. pallidum, have their first appearances in the Norwegian Sea at or just above the Miocene/Pliocene boundary. This suggests that the East Greenland Current may have formed at that time, thereby transporting arctic water into the Norwegian-Greenland Sea. $F$. filifera and I. pallidum occur in Pliocene sediments of the central Arctic Ocean (Aksu and Mudie, 1985a), indicating that there was more inflow of North Pacific water prior to the Pleistocene lowering of sea level over the Bering Strait; hence, more outflow of arctic water would also be expected. This appearance of arctic/subarctic indicators also coincides with a major reduction in the Norwegian Sea occurrence of I. patulum and I. aculeatum which are typical warm temperate North Atlantic oceanic species (Harland, 1983). In contrast, the ubiquitous opportunistic species, $O$. centrocarpum started to become abundant during the Miocene/Pliocene transition often in association with B. tepikiense which is another species that appears to be toler- 
ant of major shifts in seasonal temperature and salinity (Harland, 1983; Mudie, 1980).

5. Within the Pliocene interval, twelve cyst taxa disappear from the Norwegian Sea sites, with six of these losses occurring at the Pliocene/Pleistocene boundary. Most of these species are gonyaulacoid taxa which are common in middle Miocene sediments of the North Atlantic. It is likely that their disappearance during the late Pliocene reflects the onset of major continental glaciations in the Northern Hemisphere.

6. Another major reduction in dinocyst species occurs at or just above the lower/middle Pleistocene boundary. This involves the disappearance of Polysphaeridium zoharyi and Operculodinium israelianum which are presently dominant species in subtropical-warm temperature regions (Harland, 1983). There is a major reduction in the amplitude of palynomorph abundance cycles around this time interval, and productivity appears to diminish greatly above isotopic stage 11 (ca. $440 \mathrm{Ka}$ ). In general, the latest Pleistocene is marked by a relatively low total species diversity, with about ten species during interglacial stages and five species (mostly protoperidinioids) in the glacial stages. This pattern is consistent with detailed records from sediments of late Weichselian and Flandrian age in the southern Norwegian Sea region (Dale, 1985; Harland, 1984) and upper Pleistocene sediments in the Labrador Sea (Aksu and Mudie, 1985b). In general, there appears to be a correlation between dominance of protoperidinioids and adverse conditions of low-light levels resulting from either a thick ice cover or the discharge of sediment-laden meltwater. It is also notable that only one new gonyaulacoid cyst-form, Ataxiodinium choanum, appeared in the Norwegian Sea during the late Pleistocene, in contrast to the appearance of seven protoperidinioid taxa (B. simplex, $M$. minuta, $S$. quanta, P. faeroense cyst-form of Dale (1977), T. capitatum, Xandarodinium xanthum, and $Z$. lenticulatum). This feature seems to support previous observations (Dale, 1985; Mudie, 1980) that heterotrophic peridinioid dinoflagellates are better adapted to survive in the low-light conditions dictated by the presence of extensive sea-ice cover and low-angle irradiation north of the Arctic Circle.

\section{ACKNOWLEDGMENTS}

Special thanks are extended to Atlantic Geoscience Centre (GSC) technicians Jean Dabros and Kevin MacNeil, who patiently processed and reprocessed the samples for this study and who made it possible to examine these with an automated fluorescence miscroscope system (TAS). I also thank my colleagues, Anne de Vernal (U. de Québec à Montréal), Martin Head (University of Toronto), and Atle Scholze and Svein Manum (University of Oslo) for sharing their unpublished ODP palynomorph data. I gratefully acknowledge ODP reviewers J. Wrenn and J. Bujak and the GSC funding support for Project 820044 which made this project possible.

\section{REFERENCES}

Aksu, A. E., and Mudie, P. J., 1985a. Magnetostratigraphy and palynology demonstrate at least 4 million years of Artic Ocean sedimentation. Nature, 318:280-283.

Aksu, A. E., and Mudie, P. J., 1985b. Late Quaternary stratigraphy and paleoecology of northwest Laborador Sea. Mar. Micropaleontol., 9: 537-557.

Asku, A. E., de Vernal, A., and Mudie, P. S., in press. High resolution foraminifer, palynologic, and stable isotope records of upper Pleistocene sediments from the Labrador Sea: paleoclimatic and paleoceanographic trends. In Arthur, M., Srivastava, S., et al., Proc. ODP, Sci. Results, 105: College Station, TX (Ocean Drilling Program).

Berggren, W. A., Kent, D. V., Flynn, J. F. and Van Couvering, J. A., 1985. Cenozoic geochronology. Geol. Soc. Am. Bull., 96:14071418.

Brown, S., and Downie, C., 1984. Dinoflagellate cyst stratigraphy of Paleocene to Miocene sediments from the Goban Spur (Sites 548-
550, Leg 80). In De Graciansky, P. C., Poag, W., et al., Init. Repts. $D S D P, 80$ (Pt. 1): Washington (U.S. Govt. Printing Office), 643651 .

Boulter, M. C., and Riddick, A., 1986. Classification and analysis of palynodebris from the Palaeocene sediments of the Forties Field. Sedimentology, 33:871-886.

Bujak, J. P., 1984. Cenozoic dinoflagellate cysts and acritarchs from the Bering Sea and northern North Pacific, DSDP Leg 19. Micropaleontology, 30:180-212.

Bujak, J. P., and Matsuoka, K., 1986a. Late Cenozoic dinoflagellate cyst zonation in the western and northern Pacific. Am. Assoc. Strat. Palynol. Contr. Ser., 17:7-26.

Bujak, J. P., and Matsuoka, K., 1986b. Taxonomic re-allocation of dinoflagellate cysts from Japan and the Bering Sea. Palynology, 10: 235-241.

Costa, L. I., and Downie, C., 1979. Cenozoic dinocyst stratigraphy of Sites 403 to 406 (Rockall Plateau, IPOD, Leg 48. In Montadert, L., Roberts, D. G., et al., Init. Repts DSDP, 48: Washington (U.S. Govt. Printing Office), 513 -529.

Dale, B., 1977. New observations on Peridinium faeroense Paulsen (1905), and classification of small orthoperidinioid dinoflagellates. Br. J. Phycol. 12:241-253.

Dale, B., 1985. Dinoflagellate cyst analysis of Upper Quaternary sediments in Core GIK 15530-4 from the Skagerrak. Nor. geol. Tidsskr, 65:97-102.

Dale, B., 1986. Marine palynology. Workshop 5, Int. Oceanogr. Conf. 2d Abstracts: Woods Hole, MA (Woods Hole Oceanographic Inst.).

de Vernal, A., and Mudie, P. J., in press, a. Pliocene and Pleistocene palynostratigraphy at ODP Sites 646 and 647 , eastern and southern Labrador Sea. In Arthur, M., Srivastava, S., et al., Proc. ODP, Sci. Results, 105: College Station, TX (Ocean Drilling Program).

de Vernal, A., and Mudie, P. J., in press, b. Late Pliocene to Recent palynostratigraphy at ODP Site 645, Baffin Bay. In Arthur, M., Srivastava, S., et al., Proc. ODP, Sci. Results, 105: College Station, TX (Ocean Drilling Program).

Edwards, L.E., 1984. Miocene dinocysts from Deep Sea Drilling Project Leg 81, Rockall Plateau, eastern North Atlantic Ocean. In Roberts, D. G., Schnitker, D., et al., Init. Repts. DSDP, 81: Washington (U.S. Govt. Printing Office), 581-594.

Eldholm, O., Thiede, J., Taylor, E., et al., 1987. Proc. ODP, Init. Repts., 104: College Station, TX (Ocean Drilling Program).

Evitt, W. R., 1984. Some techniques for preparing, manipulating and mounting dinoflagellates. J. Micropaleontol., 3:11-18.

Harland, R., 1979. Dinoflagellate biostratigraphy of Neogene and Quaternary sediments of Holes 400/400A in the Bay of Biscay (Deep Sea Drilling Project Leg 48). In Montadert, L., Roberts, D. G., et al., Init. Repts. DSDP, 48: Washington (U.S. Govt. Printing Office), 531-545.

Harland, R., 1983. Distribution maps of recent dinoflagellate cysts in bottom sediments from the North Atlantic Ocean and adjacent seas. Palaeontology, 26:321-387.

Harland, R., 1984. Recent and Late Quaternary dinoflagellate cysts from the area of the Greenland-Iceland-Faroe- Scotland Ridge. $J$. Micropaleontology, 3:95-108.

Head, M. J., Norris, G., and Mudie, P. J., in press, a. New species of dinocysts and a new species of acritarch from the upper Miocene and lowermost Pliocene, ODP Leg 105 Site 646, Labrador Sea. In Arthur, M., Srivastava, S., et al., Proc. ODP, Sci. Results, 105: College Station, TX (Ocean Drilling Program).

Head, M. J., Norris, G., and Mudie, P. J., in press, b. Palynology and dinocyst stratigraphy of the late Miocene and earliest Pliocene, ODP Leg 105 Site 646, Labrador Sea. In Arthur, M., Srivastava, S., et al., Proc. ODP, Sci. Results, 105: College Station, TX (Ocean Drilling Program).

Hill, P. R., Mudie, P. J., Moran, K. and Blasco, S. M., 1985. A sealevel curve for the Canadian Beaufort Shelf. Can. J. Earth Sci., 22: $1383-1393$.

Jan du Chêne, R., 1977. Etude palynologique du Miocene superior Andalou (Espagne). Rev. Esp. Micropaleontol., 9:97-114.

Lentin, J. and Williams, G. L., 1985. Fossil dinoflagellates: index to genera and species, 1985 edition. Can. Tech. Rept. Hydrography and Ocean Sciences, 60.

Manum, S. B., 1976. Dinocysts in Tertiary Norwegian-Greenland Sea sediments (Deep Sea Drilling Project Leg 38), with observations on palynomorphs and palynodebris in relation to environment. In Tal- 
wani, M., Udintsev, G., et al., Init. Repts. DSDP, 38: Washington (U.S. Govt. Printing Office), 897-919.

Matsuoka, K., 1983. Late Cenozoic dinoflagellates and acritarchs in the Niigata District, Central Japan. Palaeontographica (Abt. B), 187: 89-154.

Matsuoka, K., 1985. Organic-walled dinoflagellate cysts from surface sediments of Nagasaki Bay and Senzaki Bay, West Japan. Bull. Faculty Liberal Arts, Nagasaka University, Nat. Sci., 25 (2): 21-115.

Mudie, P. J., 1980. Palynology of late Quaternary marine sediments, Eastern Canada (Ph. D. Dissert). Dalhousie University, Halifax, Nova Scotia, Canada.

Mudie, P. J., 1982. Pollen distribution in recent marine sediments, eastern Canada. Can. J. Earth Sci., 19:729-747.

Mudie, P. J., 1986. Palynology and dinoflagellate biostratigraphy of Deep Sea Drilling Project Leg 94, Sites 607 and 611, North Atlantic Ocean. In Ruddiman, W. F., Kidd, R. B., Thomas, E., et al., 1986, Init. Repts DSDP, 94 (Pt. 2): Washington (U.S. Govt. Printing Office), 785-812.

Mudie, P. J. and Helgason, J., 1983. Palynological evidence for Miocene climatic cooling in eastern Iceland about $9.8 \mathrm{Myr}$ ago. Nature, 303:689-692.

Mudie, P. J., and Vilks, G., 1988. Biostratigraphic correlation and biochronology. In Quaternary Geology of the East Coast Offshore, Chapter 11, in Geology of the Continental Margin off Eastern Canada, Keen, M. J., and Williams, G. L., (Eds.), Geology of Canada, Vol. 2, Geological Survey of Canada.

Piasecki, S., 1980. Dinoflagellate cyst stratigraphy of the Miocene Hodde and Gram formations, Denmark. Bull. Geol. Soc. Den., 29: 53-76.
Powell, A. J., 1986a. A dinoflagellate cyst biozonation for the Late Oligocene to Middle Miocene succession of the Langhe region, Northwest Italy, Am. Assoc. Stratigr. Palynol. Contr. Ser., 17:105-128.

Powell, A. J., 1986b. The stratigraphic distribution of Late Miocene dinoflagellate cysts from the Castellanian Superstage stratotype, Northwest Italy, Am. Assoc. Stratigr. Palynol. Contr. Ser., 17:129150.

Powell, A. J., 1986c. Latest Paleogene and earliest Neogene dinoflagellate cysts from the Lemme Section, Northwest Italy. Am. Assoc. Stratigr. Palynol. Contr. Ser., 17:83-104.

Wall, D., Dale, B., Lohmann, G. P., and Smith, W. K., 1977. The environmental and climatic distribution of dinoflagellate cysts in modern marine sediments from regions in the North and South Atlantic Oceans and adjacent seas. Mar. Micropaleotonlogy 2:121-200.

Williams, G. L., 1977. Dinocysts: their classification, biostratigraphy and paleoecology. In Ramsey, A.T.S.(Ed.), Oceanic Micropalaeontology: London (Academic Press) 1231-1325.

Williams, G. L., and Bujak, J. P., 1977. Cenozoic palynostratigraphy of offshore eastern Canada. Am. Assoc. Stratigr. Palynol. Contr. Ser. No. 5A:14-47.

Wrenn, J. H. and Kokinos, J. P., 1986. Preliminary comments on Miocene through Pleistocene dinoflagellate cysts from De Soto Canyon, Gulf of Mexico, Am. Assoc. Stratigr. Palynol., Contr. Ser. No. 17: 169-225.

Date of initial receipt: 3 August 1987

Date of acceptance: 25 March 1988

Ms 104B-174 
APPENDIX: List of dinocysts and acritarchs in range charts (Note: $\mathrm{L} \& \mathrm{~W}=$ Lentin and Williams)

Figure No.

\begin{tabular}{rrrrrr}
5 & 6 & 7 & 8 & 9 & 10 \\
\hline 1 & - & 1 & - & - & 20 \\
2 & - & 2 & 14 & - & 1 \\
3 & 3 & 3 & 8 & 2 & 2 \\
4 & 4 & 4 & 16 & 3 & 3 \\
5 & 9 & - & 9 & 18 & - \\
6 & 38 & 27 & 10 & 28 & 19
\end{tabular}

Ataxiodinium choanum Reid 1974

Brigantedinium simplex (Wall) Reid, 1977

Bitectatodinium tepikiense Wilson, 1973

Brigantedinium species group A (this paper)

Impagidinium pallidum Bujak, 1984

Impagidinium species (mostlt 1 . patulum (Wall) Stover and Evitt, 1978, and I. aculeatum (Wall) L \& W, 1981

7
- $\quad \begin{array}{lllll}6 & 2 & - & 5 & \text { Multispinula minuta Harland and }\end{array}$ Reid in Harland et al., 1980

$\begin{array}{lllllll}8 & 13 & 7 & 11 & 20 & 15 & \text { Nematosphaeropsis labyrinthea (Os- }\end{array}$ tenfeld) Reid, 1974

$\begin{array}{lllllll}9 & 14 & 8 & 3 & 6 & 6 & \text { Operculodinium centrocarpum (De- }\end{array}$ flandre \& Cookson) Wall, 1967

$\begin{array}{lllllll}10 & 8 & 9 & 4 & 30 & 7 & \text { Peridinium faeroense cyst from of }\end{array}$ Dale (1977)

$11-24-18 \quad$ Spiniferites bentori (Rossignol) Wall \& Dale, 1970

$\begin{array}{lllllll}12 & 41 & 14 & 5 & 7 & 21 & \text { Spiniferites elongatus Reid, } 1974 \text { and }\end{array}$ intergrades with Spiniferites frigidus Harland and Reid in Harland et al., 1980

$\begin{array}{lllllll}13 & 15 & 11 & 6 & 10 & 9 & \text { Spiniferites species (species other than }\end{array}$ those listed here)

$\begin{array}{lllllll}14 & 15 & 23 & 28 & 17 & 14 & \text { Tectatodinium pellitum Wall, } 1967\end{array}$

$\begin{array}{llllllll}15 & 11 & 5 & 1 & 21 & 4 & \text { Lingulodinium machaerophorum (De- }\end{array}$ flandre and Cookson) Wall, 1967

$\begin{array}{llllllll}16 & 1 & 32 & 7 & 22 & 24 & \text { Achomosphaera andalousiensis Jan }\end{array}$ du Chêne, 1977

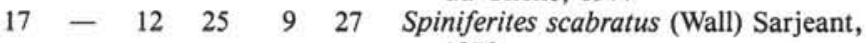
1970

$18-\quad-18-26$ Stelladinium reidi Bradford, 1975

$19-17-10$ Trinovantedinium capitatum Reid, 1977

$\begin{array}{lllllll}20 & 25 & 29 & 13 & 16 & 15 & \text { Selenopemphix nephroides Benedek, }\end{array}$ 1972

$21 \quad-\begin{array}{lllll}24 & 15 & 4 & 13 & \text { Brigantedinium species group B (this }\end{array}$ paper)

$\begin{array}{lllllll}22 & 37 & 44 & 32 & 25 & - & \end{array}$ jeant, 1970

$\begin{array}{lllllll}24 & 34 & 18 & 26 & 14 & 34 & \text { Tectatodinium species I of de Vernal }\end{array}$ and Mudie, 1988a

$\begin{array}{lllllll}24 & 18 & 19 & 17 & 15 & 25 & \text { Tectatodinium species II of de Vernal }\end{array}$ Mudie, 1988a

$2545-3124$ - Achomosphaera species A of Matsuoka, 1983

$\begin{array}{llllll}26 & 5 & 20 & - & 33 & -\end{array}$

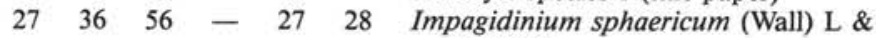
W, 1981

$\begin{array}{lllllll}28 & 30 & 16 & 23 & 29 & 30 & \text { Operculodinium israelianum (Rossi- }\end{array}$ gnol) Wall, 1967

$\begin{array}{lllllll}29 & 31 & 10 & 12 & - & 23 & \text { Polysphaeridium zoharyi (Rossignol) }\end{array}$ Bujak et al., 1980

$\begin{array}{lllllll}30 & 19 & 31 & 21 & 11 & - & -\end{array}$

$\begin{array}{lllllll}31 & - & 25 & 29 & 41 & 22 & \text { Impagidinium multiplexum (Wall and }\end{array}$ Dale) L \& W, 1981

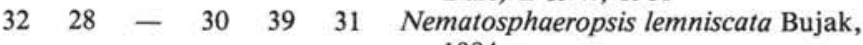
1984

$\begin{array}{lllllll}33 & 6 & 21 & 22 & 5 & 35 & \text { Filisphaera filifera } \text { Bujak, } 1984\end{array}$

$\begin{array}{lllllll}34 & 42 & 22 & 33 & 13 & - & -\end{array}$

$35-25-31-$ Palaeostomocystis species (a heterogeneous group of cysts resembling species of Palaeostomocystis Deflandre, 1973 described by Mudie (1986)
Appendix (continued).

Figure No.

\begin{tabular}{|c|c|c|c|c|c|c|}
\hline 5 & 6 & 7 & 8 & 9 & 0 & Taxon \\
\hline 6 & 2 & 15 & 17 & 1 & 23 & $\begin{array}{l}\text { Achomosphaera ramulifera (De- } \\
\text { flandre) Evitt, } 1963\end{array}$ \\
\hline & 33 & 43 & - & 32 & - & $\begin{array}{l}\text { Operculodinium crassum Harland, } \\
1979\end{array}$ \\
\hline & 20 & 35 & & & _ & osphaera umbracula Harland, \\
\hline & 27 & 36 & - & - & - & \\
\hline & 10 & & - & 34 & - & $\begin{array}{l}\text { Aaeridium species (undiffer- } \\
\text { small forms of Impletos- } \\
\text { lium Morgenroth, } 1966 \text { as } \\
\text { ed by Mudie (1986) }\end{array}$ \\
\hline & 29 & - & - & 40 & - & sphaeropsis oblonga Mudie, \\
\hline & 2 & - & - & & & $\begin{array}{l}\text { odinium echigoense Mat- } \\
a, 1983\end{array}$ \\
\hline & - & 34 & - & 43 & 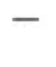 & um 1983 longispinigerum \\
\hline & 23 & & & & & um walli \\
\hline & 40 & - & & & & nium harlandi Matsuoka, \\
\hline & 39 & 28 & 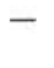 & (1) & & $\begin{array}{l}\text { odinium species of Jan du } \\
\text { e, } 1977\end{array}$ \\
\hline & 8 & 38 & - & 35 & - & poma species of Edwards \\
\hline & 17 & 30 & - & 37 & 38 & $\begin{array}{l}\text { nium simplex (Harland) Ed- } \\
1984\end{array}$ \\
\hline 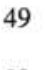 & 24 & - & - & 48 & - & tidia species 1 of Mudie \\
\hline & - & 4 & - & 44 & - & thodinium species 1 (this pa- \\
\hline & 12 & 33 & - & 47 & & $\begin{array}{l}\text { phaeridium choanophorum } \\
\text { flandre \& Cookson) Harland } \\
\text { Hill, } 1979\end{array}$ \\
\hline
\end{tabular}

$53 \quad 3538-1-\quad-\quad$ Hystrichosphaeropsis pontiana (Baltes) Stover and Evitt, 1978

$54-\quad-\quad 46-$ Batiacasphaera sphaerica Stover, 1977

$55-53-\ldots$ - Spiniferites pachyderma (Rossignol)

$56-37 \quad-\quad-\quad \begin{gathered}\text { Reid, } 1974 \\ \text { Dapsilidinium pastielsii (Davey \& Wil- }\end{gathered}$

liams) Bujak et al., 1980

$\begin{array}{lllllll}57 & 32 & 47 & - & - & - & \text { Reticulatosphaera actinocoronata }\end{array}$ (Benedek) Bujak and Matsuoka, 1986b

$58-49-\quad-\quad$ Batiacasphaera species II of Edwards (1984)

$59 \quad-55 \quad-\quad$ - Cyclopsiella elliptica Drugg \& Loeblich, 1967

$60-50-\ldots$ - Hystrichosphaeropsis obscura Habib, 1972

$61-46--\quad-$ Operculodinium species of Piasecki (1980)

$62-54-\infty \quad$ Impagidinium aquaeductum (Piasecki) L \& W, 1985

$63-57-\quad-\quad$ Labyrinthodinium truncatum Piasecki, 1980

64 - 58 - - Pentadinium laticinctum Gerlach, 1961

$65-63-$ - Systematophora placacantha (Deflandre \& Cookson) Davey et al., 1969

$66-48--\quad-$ Tectatodinium species of Piasecki (1980)

- 7 - $-\quad$ Hystrichokolpoma species 1 of Mudie (1986)

- 2140 - 40 Invertocysta species (mostly I. lacymosa Edwards, 1984)

- 51 - $\quad$ - Invertocysta tabulata Edwards, 1984 
Appendix (continued).

\begin{tabular}{|c|c|c|c|c|c|c|}
\hline \multirow{2}{*}{5} & \multicolumn{4}{|c|}{ Figure No. } & \multirow[b]{2}{*}{10} & \multirow[b]{2}{*}{ Taxon } \\
\hline & 6 & 7 & 8 & 9 & & \\
\hline- & 26 & - & - & - & 8 & $\begin{array}{l}\text { Selenopemphix quanta (Bradford) } \\
\quad \text { Matsuoka, } 1985\end{array}$ \\
\hline- & 43 & - & - & - & - & $\begin{array}{l}\text { Quinquecuspis species (undifferenti- } \\
\text { ated) }\end{array}$ \\
\hline- & - & 45 & - & - & 12 & $\begin{array}{l}\text { Tuberculodinium vancampoae (Rossi- } \\
\text { gnol) Wall, } 1967\end{array}$ \\
\hline - & - & 59 & - & - & - & $\begin{array}{l}\text { Dinopterygium verriculum Piasecki, } \\
\quad 1980 \\
=\text { Heteraulacacysta } \text { (Piasecki) L \& W, } \\
\quad 1981\end{array}$ \\
\hline- & - & 60 & - & - & - & $\begin{array}{l}\text { Hystichosphaeropsis obscura Habib, } \\
1972\end{array}$ \\
\hline- & - & 62 & - & - & - & $\begin{array}{l}\text { Palaeocytodinium species A of Brown } \\
\text { and Downie (1984) }\end{array}$ \\
\hline- & - & 64 & - & - & - & $\begin{array}{l}\text { Achomosphaera crassipellis (De- } \\
\text { flandre \& Cookson) Stover and } \\
\text { Evitt, } 1978\end{array}$ \\
\hline- & - & 65 & - & - & - & $\begin{array}{l}\text { ?Thalassiphora cf. Th. ?pensa Stover, } \\
1977\end{array}$ \\
\hline- & - & 66 & - & - & - & $\begin{array}{l}\text { Palaeocystodinium golzowense Al- } \\
\text { bert, } 1961\end{array}$ \\
\hline- & - & 67 & - & - & - & $\begin{array}{c}\text { Emslandia spiridoides (Benedek) } \\
\text { Benedek and Sarjeant, } 1981\end{array}$ \\
\hline- & - & - & 20 & 12 & 32 & $\begin{array}{l}\text { Quinquecuspis species (undifferenti- } \\
\text { ated) }\end{array}$ \\
\hline- & - & - & 27 & - & - & $\begin{array}{l}\text { Selenopemphix cf. species B of Powell } \\
\text { (1986b) }\end{array}$ \\
\hline- & - & - & 34 & 26 & 29 & $\begin{array}{l}\text { ?Cordosphaeridium species } 1 \text { of de } \\
\text { Vernal and Mudie, } 1988 \mathrm{~b}\end{array}$ \\
\hline- & - & - & - & 8 & - & $\begin{array}{l}\text { Spiniferites pseudofurcatus (Klumpp) } \\
\text { Sarjeant, } 1970\end{array}$ \\
\hline . & - & - & - & - & 11 & Xandarodinium xanthum Reid, 1977 \\
\hline 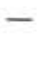 & - & - & - & - & 17 & $\begin{array}{l}\text { Zygabikodinium lenticulatum (Wall \& } \\
\text { Dale) Bujak and Davis, } 1983\end{array}$ \\
\hline
\end{tabular}



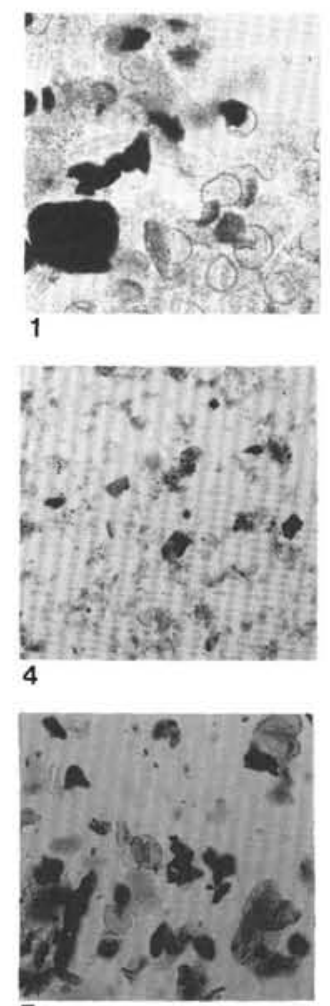

7

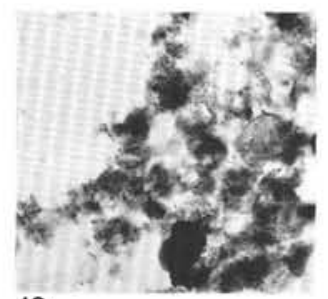

10

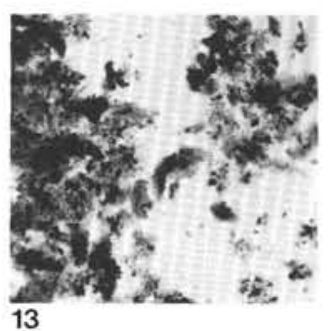

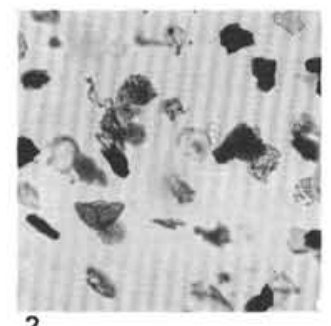

2

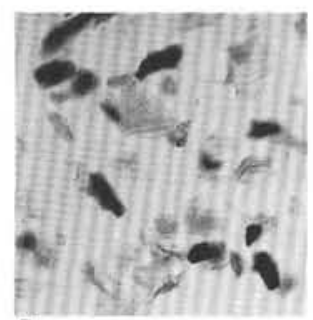

5
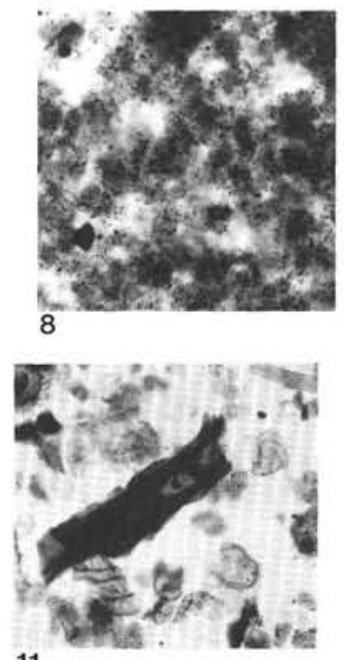

11

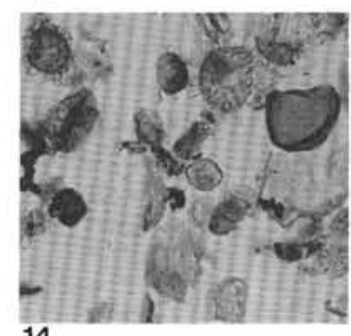

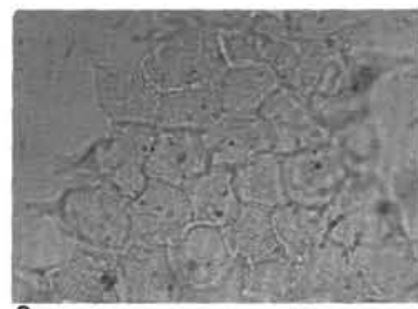

3
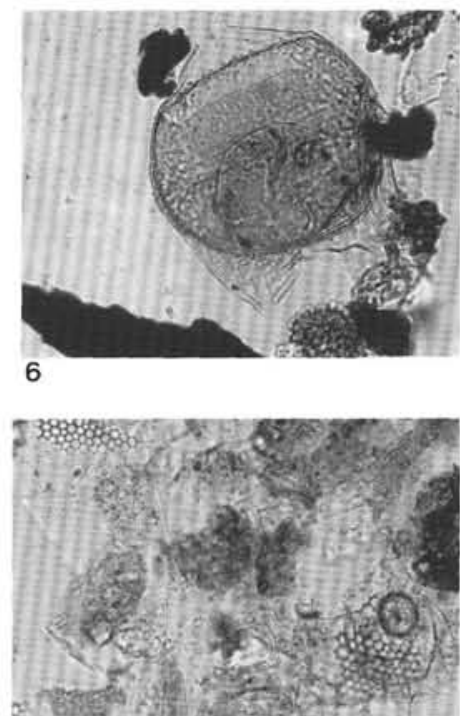

9

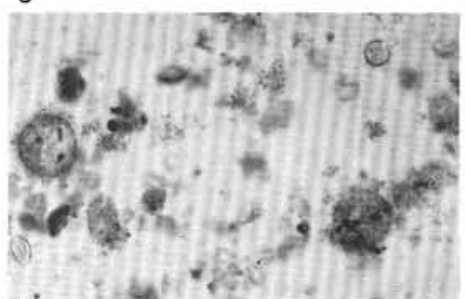

12

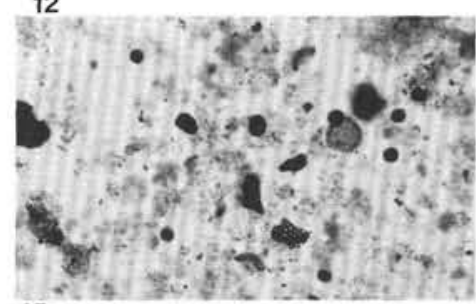

15

Plate 1. Magnification $\times 160$ for all figures except 3 and $6(\times 1000)$ and $9(\times 400) . \quad 1,2,3,6$. Upper Pleistocene palynofacies. 1, 3: Interglacial stage marine palynofacies; 1. 104-642B-1 H-1, 0-5 cm: indigenous dinocysts embedded in yellow amorphous debris, with scattered wood fragments and black debris. 3. 104-644B-6H-4: Pediastrum coenobium. 2, 6: Ice-rafted palynofacies; 2. 104-642B-2H-6, 41-43 cm: large wood fragments, black debris, redeposited (Cretaceous-Paleogene) palynomorphs; 6. 104-644B-2H-6, 86-88 cm: well-preserved Paleogene dinocyst and poorly sorted wood fragments. 4, 5, 7. Upper Pliocene-lower Pleistocene palynofacies, Site 642. 4. 104-642-7H-5, 62-64 cm: marine palynofacies with well-dispersed small flocs of yellowish amorphous debris, small particles of wood and black debris; 5. 104-642B-7H-7, 62-64 cm: ice-rafted or fluviatile palynofacies with large wood and leaf fragments, degraded debris, poorly preserved reworked Tertiary palynomorphs; 7. 104-642B-5H-1, 71$78 \mathrm{~cm}$ : terrigenous or fluviatile palynofacies with abundant pollen, coarse wood fragments, black debris and reddish brown degraded debris. $\mathbf{8}, \mathbf{1 1}$. Upper Pliocene palynofacies, Site 644. 8. Marine palynofacies, 104-644A-29H-2, 35-37 cm: palynomorphs embedded in dense masses of dark brown amorphous debris with black specks; 11 . 104-644A-34H-5, 85-87 cm: terrigenous palynofacies, with dinocysts and pollen interspersed with large wood particles, rare small flocs of amorphous debris. 9, 12, 15. Biosiliceous palynofacies. 9. Lower Pleistocene 104-644A-16H-4, 35-47 cm: dinocysts in matrix of amorphous yellow debris, faecal pellets, diatom fragments and resting spores, with thin sheets of translucent siliceous shards; 12. Upper Miocene 104-642C-11H-6, 136-137 cm: dinocysts coated with amorphous debris and black specks, interspersed with irregular and pellet-shaped flocs of amorphous debris. 15. Lower Pliocene 104-642C-11H-1, 19-20 cm: dinocysts interspersed with amorphous debris and black specks, common pyritised black spores (?diatoms), rare pyritized diatom fragments and reddish brown degraded debris. 10, 13. Upper Miocene-middle Pliocene palynofacies, Site 642. 10. 104-642B-8H-2, 61-63 cm: Pliocene dinocysts interspersed with or embedded in large flocs of brown amorphous debris with abundant black flecks and rare degraded brown debris; 13. 104-642B-16,CC: Upper Miocene dinocysts embedded in subangular flocs of brown amorphogen with abundant poorly sorted unstructured debris. 14. Lower-middle Miocene palynofacies, 104-643A$18 \mathrm{H}, \mathrm{CC}(0-8 \mathrm{~cm})$. Abundant dinocysts with rare flocs of yellowish amorphous debris and wood fibers. 


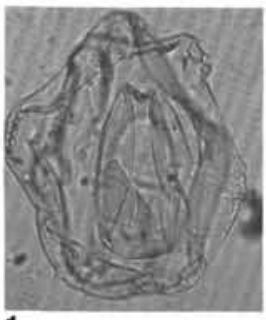

1

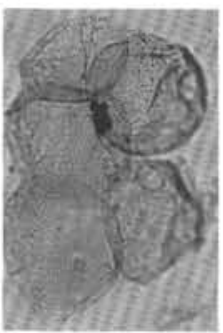

5

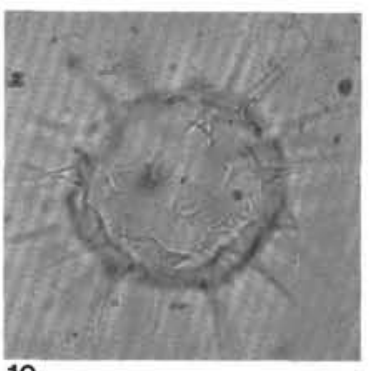

10

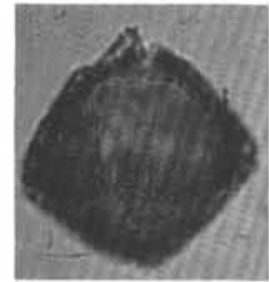

2

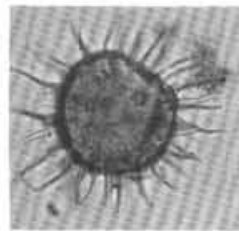

6

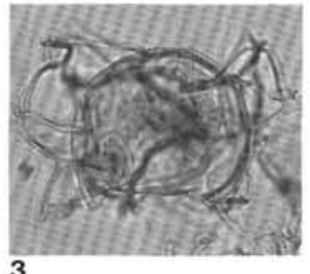

3

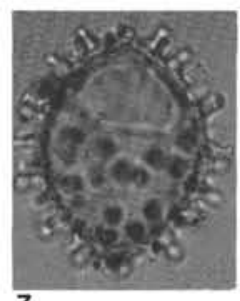

7

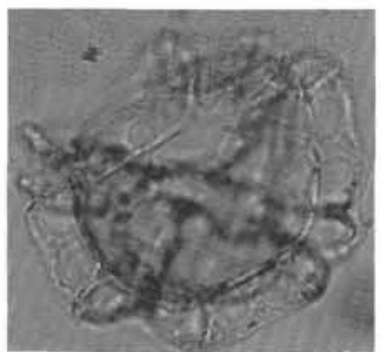

11

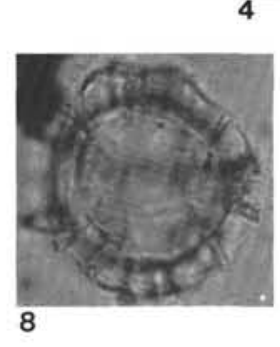

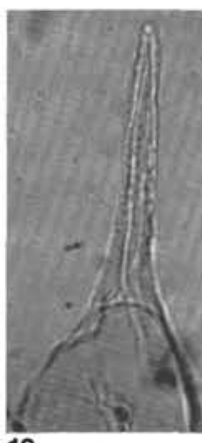

12

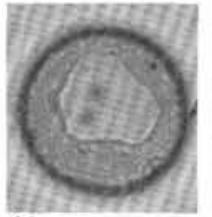

16
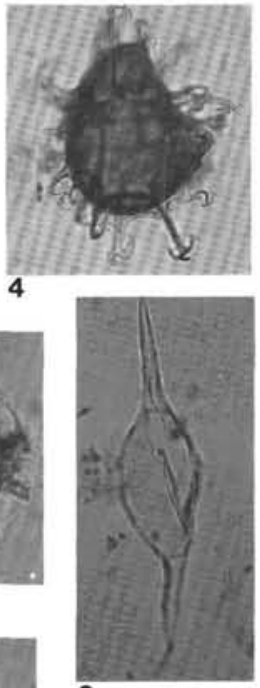

9

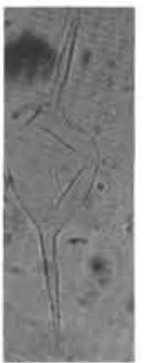

13

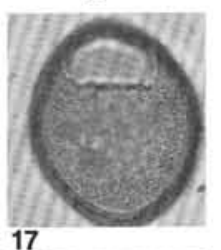

17

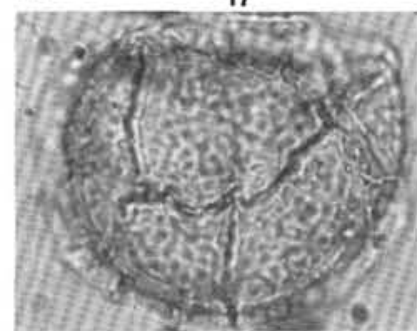

18

14

15

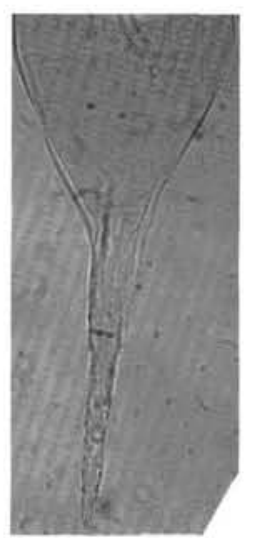

Plate 2. Magnification is $\times 400$ for Figures $1-6,9,13$, and $\times 1000$ for Figures 7,8,10,12 and 14-18. 1. ?Thalassiphora sp. cf. Th. pansa; 104-643A$14 \mathrm{CC}(10-12 \mathrm{~cm})$, AGC 870226-15 (K30/4). Dorsal view, mid focus. 2, 14. Emslandia spiridoides, 104-643A-18H,CC (0-8 cm), AGC 870318-25 (G50/3); 2. Dorsal view, surface focus; 14. Dorsal view, posterior archeopyle margin and surface ornament in focus. 3. ?Evittosphaerula sp. 1, 104-643A-20H,CC (0-8 cm), AGC 870318-29 (U42/0): surface focus, orientation uncertain. 4. Spiniferites ?pachydermus, 104-643A-15H,CC (34$36 \mathrm{~cm})$; AGC 870318-14 (X24/2): lateral view, mid focus. 5. Cyclopsiella elliptica, 104-643A-14H,CC (12-14 cm), AGC 870226-36 (O48/0): surface focus on a "chain" of five cysts. 6. Operculodinium walli, 104-644A-7H-1, 1-73 cm, AGC 870205-1 (Z25/3): left lateral view, mid focus. 7. Operculodinium sp. of Piasecki (1980), 104-643A-8H,CC (28-30 cm), AGC 870206-1 (N47/0): dorsal view, mid focus. 8. Labyrinthodinium truncatum, 104-643A-14H,CC (10-12 cm), AGC 870318-36 (Z36/0), dorsal view, mid focus. 9, 12, 13, 15. Palaeocystodinium sp. A of Costa and Downie (1979), 104-643A-13H,CC (20-22 cm). 9, 12. AGC 870318-7 (T43/3): dorsal view of cyst with an elliptical body; focus on the apical horn; 12. Apical horn, mid focus, with finely echinate ornament. 13. AGC 870318-5 (W48/1): left lateral view of cyst with a subsphaerical body, focus on antapical horn. 15. AGC 870318-11 (Q38/1): surface focus on antapical horn of cyst with an ellipical body, fine axial striation and micropapillate ornament. 10. Dapsilidinium pastielsii al., 1980, 104-643A-9H,CC $(9-11 \mathrm{~cm})$, AGC 870226-13 (E23/3): oblique apical view, mid focus; apical archeopyle faintly visible upper right. 11. Impagidinium aquaeductum, DSDP 338-8-2, 30-34 cm, EPG P14492-01 (Z40/1): dorsal mid focus. 16. Batiacasphaera sphaerica, 104-643A-13H,CC (20-22 cm), AGC 870318-17 (W36/2): apical view. 17. Pyxidiella simplex, 104-643A-19H,CC (17-19 $\mathrm{cm})$, AGC 870318-28 (H40/3): dorsal mid focus. 18. ?Dinopterygium verriculum, 104-643A-13H,CC (17-19 cm); AGC 870226-35 (Z47/1): right lateral view, hypocyst surface in focus. 


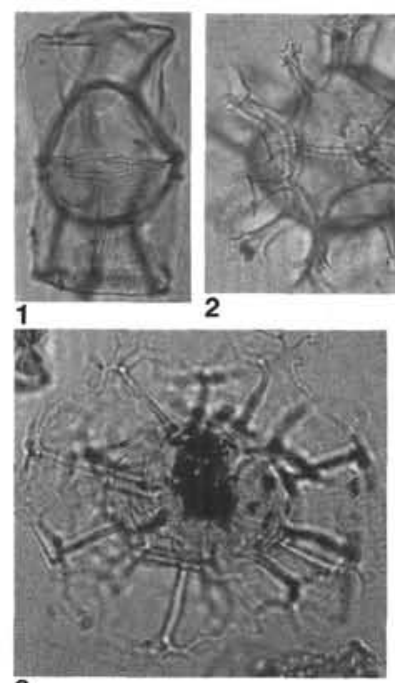

6

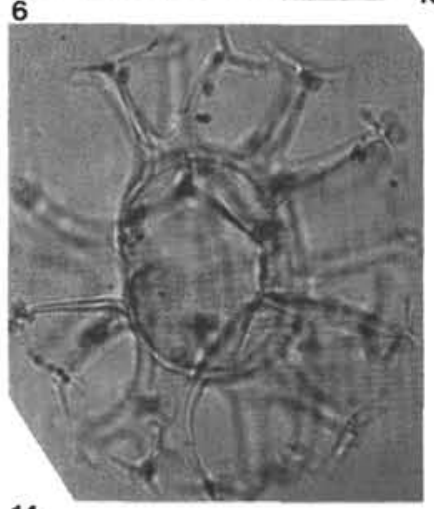

14

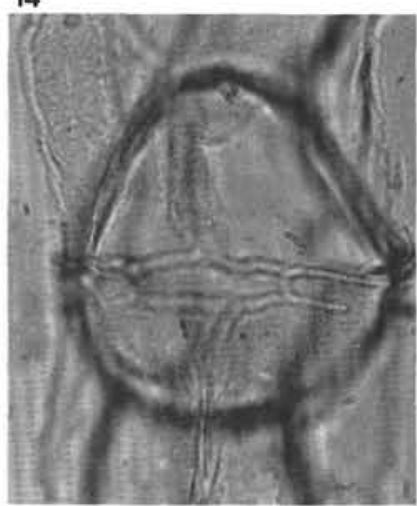

17
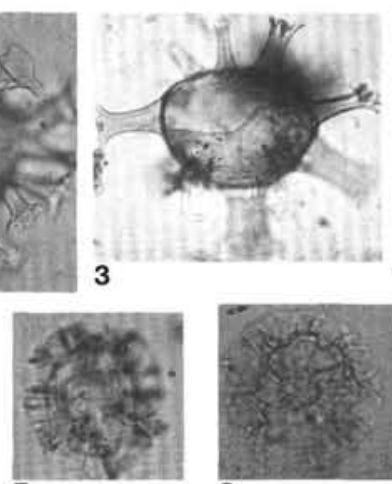

7

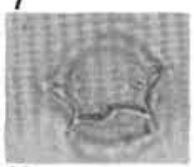

10

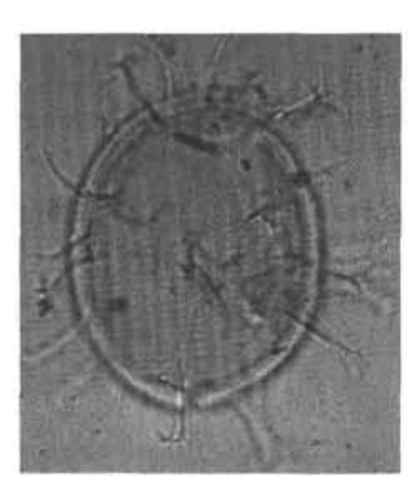

15

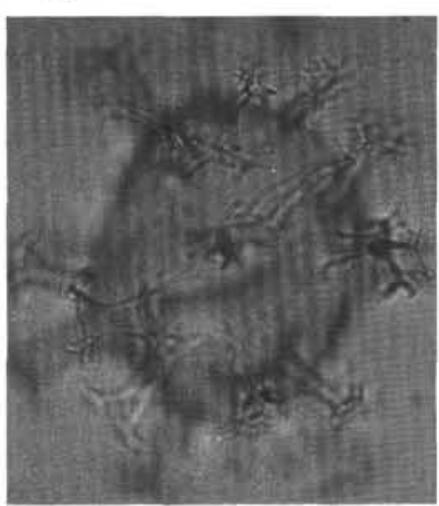

18

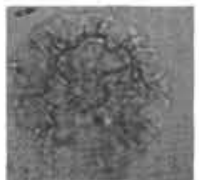

8

12
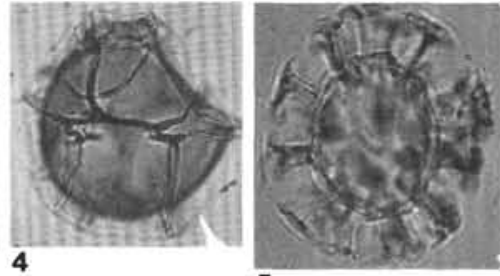

5

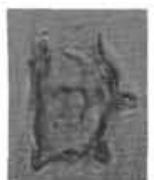

9
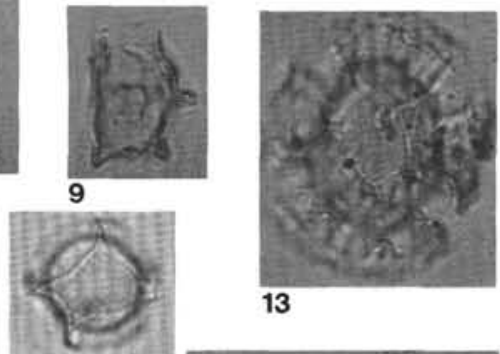

13

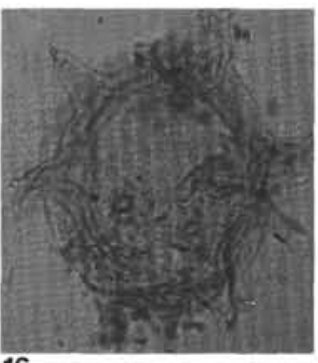

16

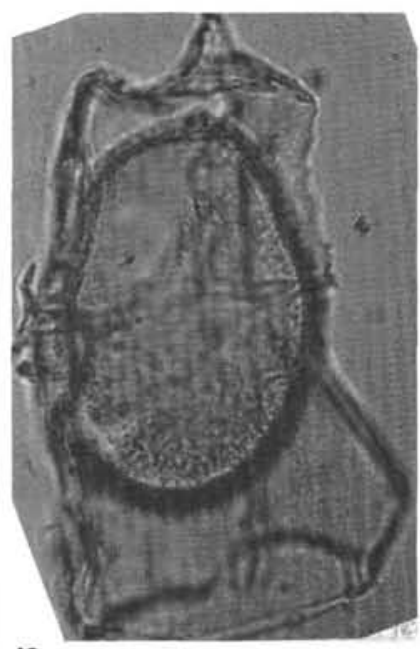

19

Plate 3. Magnification $\times 400$ for Figures $1-4$, and $\times 1000$ for Figures 5-19. 1,17 Hystrichosphaeropsis ?pontiana, 104-643A-9H,CC (9-11 cm), AGC 870226-30 (E22/0). 1. Dorsal mid focus; 17. dorsal surface focus, showing the smooth ovate body, wide cingulum, and finely scabrate periphragm surface. 2, 3 Hystrichokolpoma sp. of Edwards, 1984. 2. 104-643A-16H,CC (23-25 cm); AGC 870226-22 (N25/2): ?Left lateral surface. 3. 104-642B-19H,CC (9-11 cm), AGC 870122-15 (Z14/1): Apical mid focus. 4. Pentadinium laticinctum, 104-643A-13H,CCG (20-22 cm), AGC 870318-1 (W25/0: Ventral surface. 5, 13 ?Labyrinthodinium sp. 1. 104-643A-8H,CC (28-30 cm), AGC 870226-7 (R27/4). 5. Optical section, orientation unknown; 13. Surface of trabeculate periphragm. 6. Reticulatosphaera actinocoronata 104-643A-14H,CC (10-12 cm), AGC $870226-$ 16 (M31/0): Optical section. 7, 8 ?Cymatiosphaera sp. 1. 104-644A-24H-1, 35-37 cm; 7. AGC 870404-1 (N19/3). Optical section of crests separated at the distal ends in places. 8 AGC 870404-2 (N17/0). Surface of undulating margins of crest fields. 9, 10, 11, 12. Platycystidia sp. $1104-642 \mathrm{C}-11 \mathrm{H}-1$, 38-39 cm. 9. AGC 870404-3 (P48/1). Surface of specimen with rectangular body, showing ?apical separation of outer wall layer 10, 11, 12. AGC 870122-1 (W55/0). Apical view of specimen with circular body. 10. Surface, showing small pylome with subrectangular outline; 11. Optical section; 12. Antapical focus. 14. Spiniferites sp. "TS". 104-643A-8H,CC (28-30 cm), AGC 870226-4 (F37/3): Optical section of long narrow gonal spines with trifurcate distal ends. 15. Achomosphaera ?crassipellis, 104-643A-11H,CC (42-44 cm), AGC 870318-35 (D34/2): Dorsal tectate body wall. 16. Achomosphaera ?sp. A of Matsuoka (1983). 104-644A-16H-3, 135-137 cm, AGC 870205-11. (Z45/1: Dorsal surface focus. 18. Achomosphaera andalousiensis. 104-642A-1H-4, 100-102 cm, AGC 870220-20 (E19/4). Orientation uncertain, focus on process tips, with complex branching and fusion of tips. 19. Hystrichosphaeropsis obscura 104-643A-8H,CC (28-30 cm); AGC 870226-5 (E28/3). Surface view of ellipsoidal central body with coarsely tectate ornament and granular appearance. 

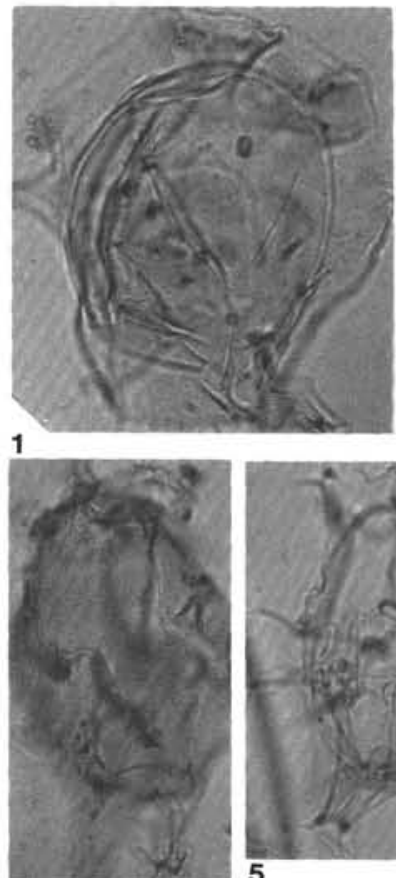

4
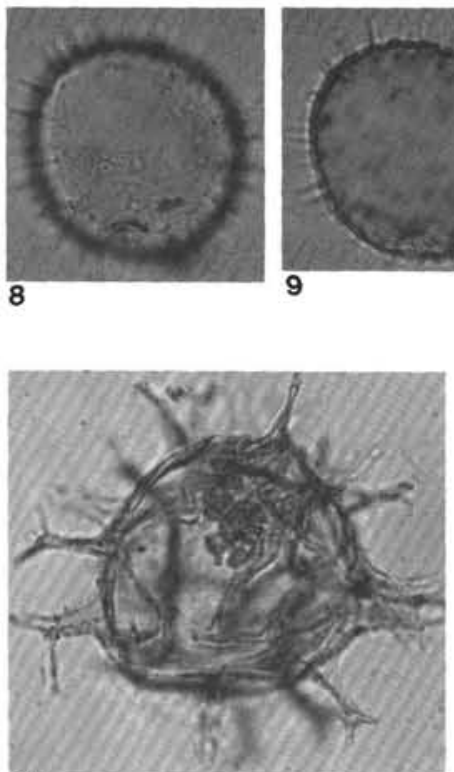

12

5

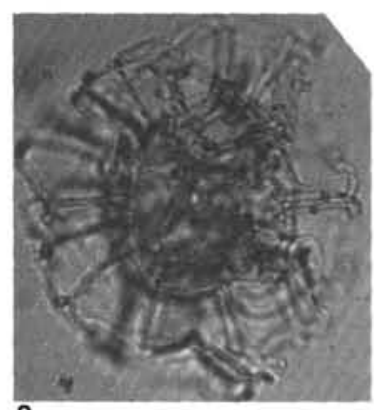

2
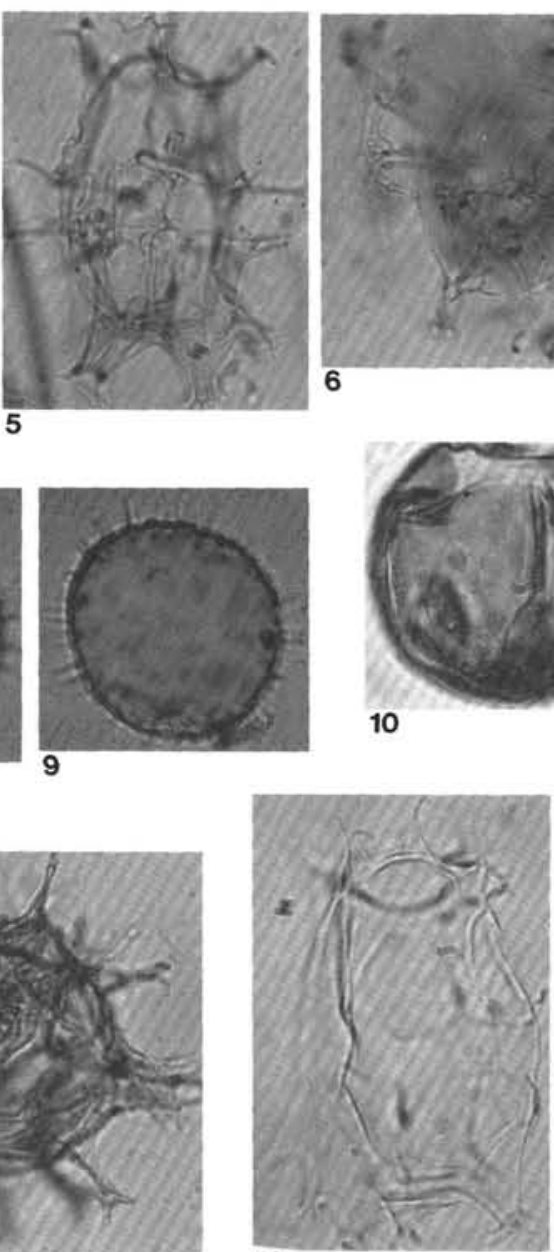

13

10

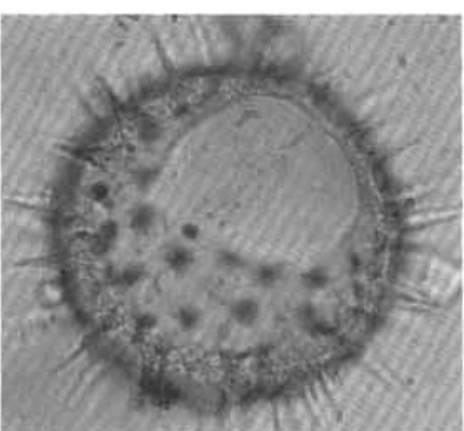

3

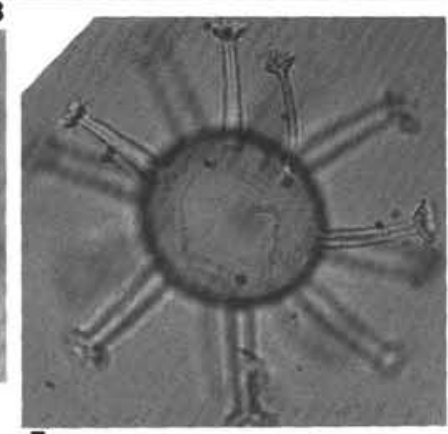

7
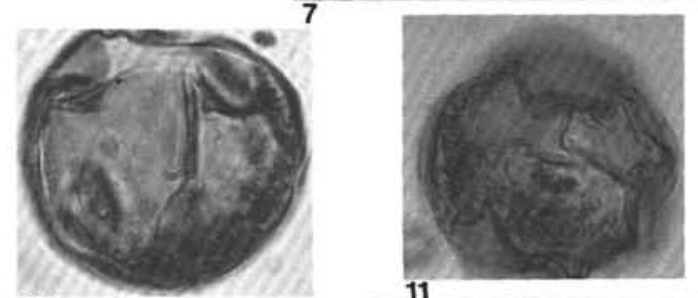

11

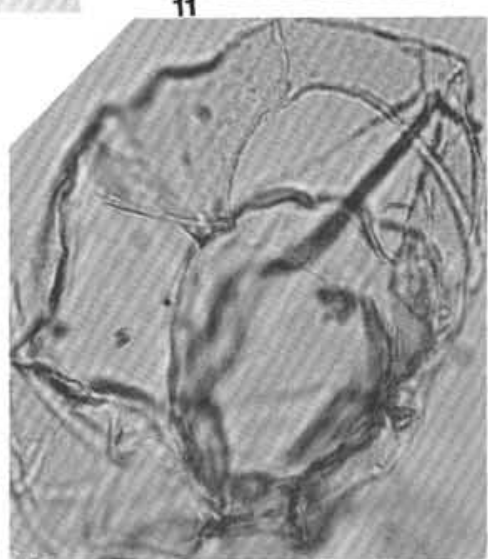

14

Plate 4. Magnification $\times 1000$. 1, 4 Spiniferites rubinus (Rossignol) 1. 104-642B-7H-3, 62-64 cm, AGC870220-32 (W18/1): Dorsal surface of cyst with wide crests linking gonal processes. 4. 104-644A-16H-3 (135-137 cm, AGC870205-35 (U45/0): Dorsal view of weak, box-like gonal processes. 2, 6 Nemotosphaeropsis lemniscata 104-644A-10H-3, 135-137 cm, AGC870318-23 (T39/4): 2. ?Right lateral, optical section. 6. Surface of undulating ribbon-like trabeculae. 3. Operculodinium crassum, 104-642C-11 H-4, 42-43 cm, AGC870122-20 (W33/2): Dorsal mid focus. 5, 13 Spiniferites elongatus-frigidus intergrades. 5. S. elongatus cyst type; 104-644A-16H-2, 35-37 cm, AGC $870205-7$ (U29/1) 5. Dorsal surface figure. 13. S. frigidus cyst type. 104-642A-1H-6 100-102 cm, AGC870220-22 (Z38/3): Dorsal mid focus. 7. Melitasphaeridium choanophorum, 104643A-8H,CC (28-30 cm), AGC870206-6 (D30/0): Dorsal epicyst, apical process in focus. 8, 9 Peridinium faeroense cyst form of Dale (1977). 104642A-1H-2, 100-102 cm, AGC 870220-13 (U18/1): 8. ?Apical view of outer wall surface; 9. Optical section of the variable spine length. 10. Brigantedinium species group B. 104-644B-6H-2, 86-88 cm, AGC 870318-18 (G24/0): Dorsal antapical surface. 11. Selenopemphix ?sp. B of Powell (1986b). 104-644A-10H-5, 85-87 cm, AGC870404-7 (Z47/4). Right lateral eipcyst surface. 12. Spiniferites scabratus 104-644B-15H-2, 86-88 cm, AGC870318-32 (Z50/4): Dorsal epicyst surface showing microgranular ornament on processes. 14. Amiculosphaera umbracula 104-644A-29H-2, 85-87 cm, AGC870205-38 (O44/4): Dorsal apical periphragm arch in focus. 


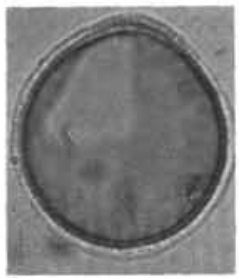

1
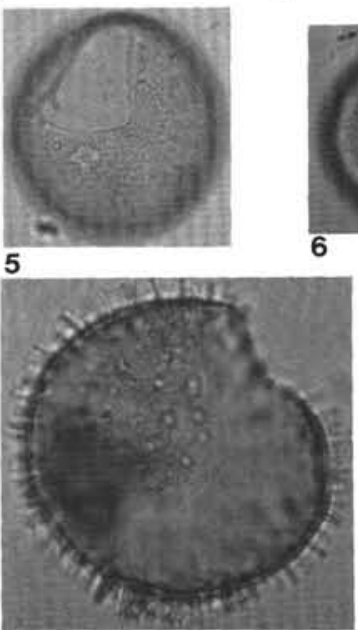

9

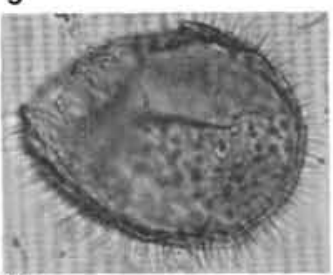

12

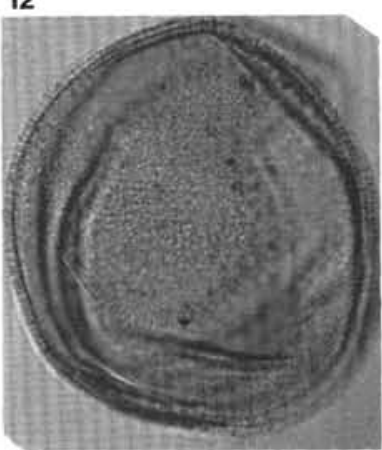

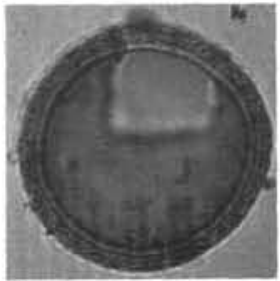

2

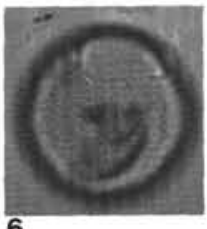

6

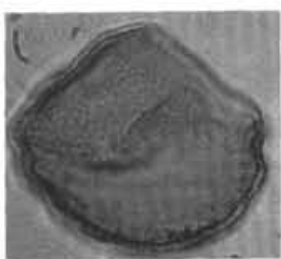

3

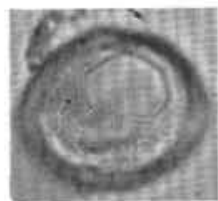

7

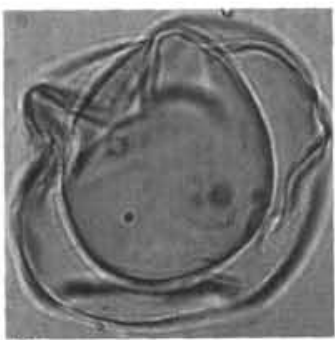

10

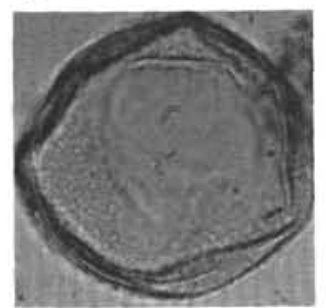

13

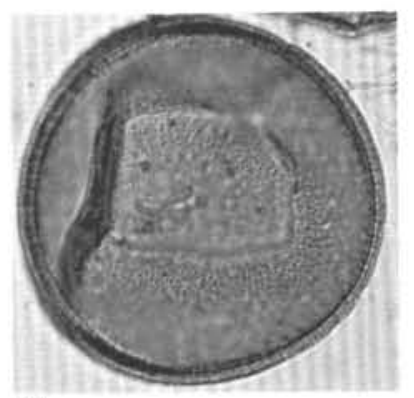

15

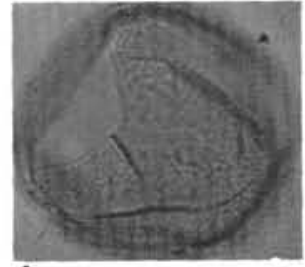

4

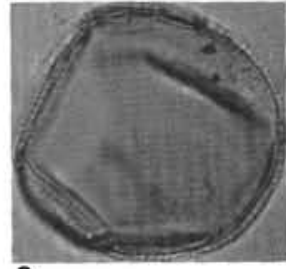

8

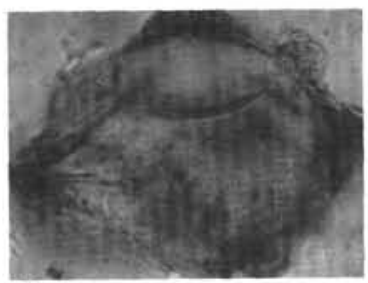

11

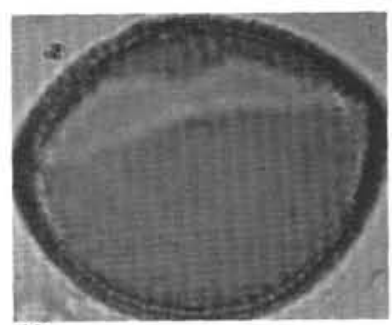

16

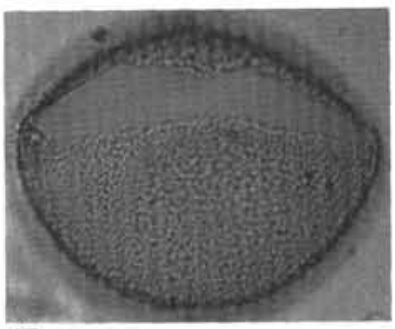

17

Plate 5. Magnification $\times 1000$ 1, 5 Tectatodinium pellitum 104-642A-1H-2, 100-102 cm, AGC870220-26 (Z16/1). 1. Dorsal optical section of outer wall layer and tectate ornament. 5. Surface of finely corrugated ornament. 2. ?Tectatodinium sp. of Piasecki, 1980. 104-643A-8H,CC (28$30 \mathrm{~cm}$ ), AGC870220-35 (O46/4): Dorsal optical section. 3. Tectatodinium sp. III. 104-644A-24H-3, 35-37 cm, AGC870213-17 (W30/3): ?Ventral view, mid focus on paracingulum and tectate wall. 4, 8 Dinocyst sp. 1. 104-644A-29H-2, 35-37 cm, AGC870213-11 (O43/0) 4. ?Right lateral surface. 8. Optical section of coarsely tectate ornament. 6, 7 ?Pyxidiella sp. 1. 104-643A-13H,CC (20-22 cm), AGC870318-12 (Y37/0): 6. Surface of specimen with notched apical pylome. 7. AGC870318-13 (W45/0): Apical view of specimen with pentagonal pylome. 9, 12 Multispinula minuta: 9. 104-642A-1 H-4, 100-102 cm, AGC870220-21 (X29/4): Left lateral optical section of short, acuminate processes and attached archeopyle; 12. Sample 104-644B-1H-1, 100-102 cm; AGC860413-2 (Y31/4): Dorsal optical section of cyst form with acicular processes (wall on right is torn). 10. Ataxiodinium choanum 104-642A-1H-2 100-102 cm, AGC870220-12 (O37/0): Dorsal surface. 11. ?Cordosphaeridium sp. 1. 104-644A-17H-2, 31-33 cm, AGC 870205-30 (W38/2): ?Dorsal optical section. 13. Tectatodinium sp. II. 104-644A-24-3, 84-87 cm, AGC870404-5 (K12/0): Dorsal optical section of surface. 14. Filisphaera filifera, 104-642B-7H-4, 62-64 cm, AGC870220-33 (T23/1): Left lateral mid focus on thin finely granular outer wall and pilose ornament. 15. Tectatodinium sp. I. 104-644A-16H-4 (35-37 cm, AGC870205-17 (P15/1): Dorsal optical section of thick outer wall, coarsely tectate ornament and finely corrugate wall surface. 16, 17 Bitectatodinium tepikiense, 104-642A-1H-2, 100-102 cm, AGC870220-25 (Y40/4): 16. Dorsal optical section of thick outer wall and coarsely tectate ornament; 17. Surface of heavily corrugate outer wall. 